\title{
Review Article \\ The Biological Side of Water-Soluble Arene Ruthenium Assemblies
}

\author{
Bruno Therrien ${ }^{1}$ and Julien Furrer ${ }^{2}$ \\ ${ }^{1}$ Institut de Chimie, Université de Neuchâtel, Avenue de Bellevaux 51, 2000 Neuchâtel, Switzerland \\ ${ }^{2}$ Departement für Chemie und Biochemie, Universität Bern, Freiestraße 3, 3012 Berne, Switzerland
}

Correspondence should be addressed to Julien Furrer; julien.furrer@dcb.unibe.ch

Received 4 March 2014; Accepted 23 April 2014; Published 17 July 2014

Academic Editor: Fazlul Haq

Copyright (C) 2014 B. Therrien and J. Furrer. This is an open access article distributed under the Creative Commons Attribution License, which permits unrestricted use, distribution, and reproduction in any medium, provided the original work is properly cited.

\begin{abstract}
This review article covers the synthetic strategies, structural aspects, and host-guest properties of ruthenium metalla-assemblies, with a special focus on their use as drug delivery vectors. The two-dimensional metalla-rectangles show interesting host-guest possibilities but seem less appropriate for being used as drug carriers. On the other hand, metalla-prisms allow encapsulation and possible targeted release of bioactive molecules and consequently show some potential as drug delivery vectors. The reactivity of these metalla-prisms can be fine-tuned to allow a fine control of the guest's release. The larger metalla-cubes can be used to stabilize the formation of G-quadruplex DNA and can be used to encapsulate and release photoactive molecules such as porphins. These metalla-assemblies demonstrate great prospective in photodynamic therapy.
\end{abstract}

\section{Introduction}

Anticancer platinum complexes dominate the field of metals in cancer chemotherapy, mainly because of the considerable research effort that followed the fortuitous discovery of the anticancer property of cisplatin (Figure 1) in the late 1960s [1]. Unfortunately, the use of cisplatin is restricted because of severe dose-limiting side effects, which arise from the indiscriminate uptake of the drug into all rapidly dividing cells. Indeed the platinum atom is known to efficiently bind to serum proteins, especially human serum albumin (HsA) [2]. Once inside cells, aquated cisplatin species will mainly bind at the N7 position of guanine, leading to significant distortions of the DNA helix [3]. These DNA lesions are thought to prevent replication and transcription and ultimately to lead to cellular apoptosis [3].

The severe side effects of cisplatin have led to a massive investigation into the cytotoxicity and genotoxicity of platinum-based compounds, in order to elucidate their molecular mechanisms and identify key biomolecular targets for rational drug design [6-8]. In the 30 years since cisplatin's first approval for human use, only two compounds have been approved worldwide (oxaliplatin and carboplatin, Figure 1) and another three gaining marketing approval in individual nations (Nedaplatin, Lobaplatin, and Heptaplatin) [4]. Currently, there are four mononuclear platinum drugs in various stages of clinical trials, with two of these being close to clinical recognition (satraplatin [9] and picoplatin [10]). Two other drugs (ProLindac and Lipoplatin) [11-14] will become the first polymer/liposomal-based platinum drugs on the market if approved [4].

Synthesized and developed contemporarily to mononuclear platinum complexes, polynuclear platinum compounds have received a great deal of attention [15]. One of these compounds, triplatin tetranitrate (BBR3464, Figure 2) $[5,16$, 17], has entered four consecutive phase II trials, three of them unsuccessful, and the drug has never moved into phase III [4]. The results of the remaining phase II clinical trial on metastatic pancreatic cancer which started in 2001 have yet to be published. However, it was reported that BBR3464 causes so severe large dose-limiting side effects where the maximum tolerated dose (MTD) in humans was considerably lower than the MTD for all the platinum-based drugs currently used in the clinic [18]. 

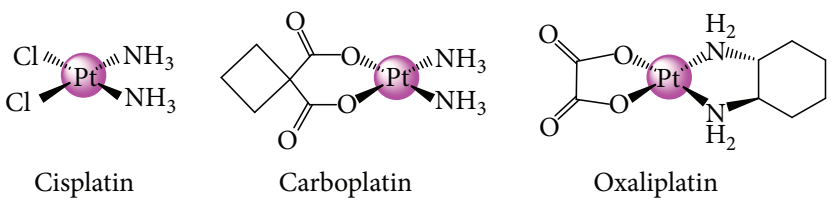

FIGURE 1: The three platinum-based anticancer drugs, cisplatin, carboplatin, and oxaliplatin, which have gained worldwide marketing approval for humans [4].

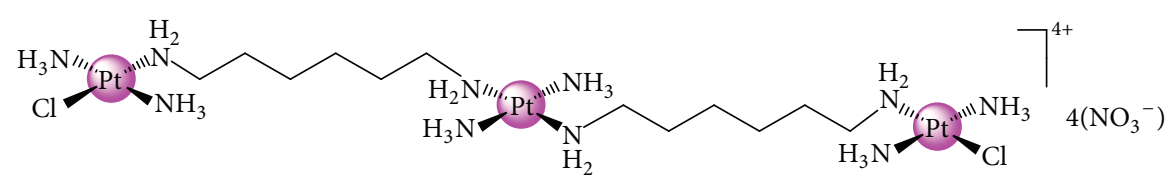

FIGURE 2: Structure of the first polynuclear platinum compound, triplatin tetranitrate (BBR3464), that has entered clinical trials [5].

A challenge of anticancer treatment is the specific delivery of the drugs in order to avoid deleterious effects on normal cells. In fact, most of the inorganic anticancer drugs have potent effects also on normal cells due to the strong similarity of the mechanisms of growth regulation of normal cells as compared to their transformed counterparts.

Recent developments in nanotechnology have aimed at delivering anticancer drugs in tumor tissue via encapsulation in the so-called drug delivery systems $[19,20]$. The delivery strategy of anticancer drugs is based upon the particular structure of tumor neoangiogenic vessels that allow the passive targeting or enhanced permeability and retention effect (EPR effect) [21]. The addition of targeting moieties on the surface of such drug delivery systems, such as specific antibodies recognition moieties, can further enhance the active targeting to tumor cells. As such, a lot of effort has been put into the development of such systems that would alleviate the inherent toxicity of platinum drugs and resistance issues. Liposomes [22], polymers [23-25], dendrimers [26], organic macrocycles [27], nanoparticles [28], viruses [29], and carbon nanotubes $[30,31]$ have all shown promises as drug delivery vehicles for platinum therapeutics.

Metalla-assemblies have started to attract considerable attention, but these systems have remained relativity unexplored as drug delivery vectors [32]. The assembly of transition-metal complexes with polydentate ligands to give discrete supramolecular structures has been studied by several groups. Pioneered by Fujita et al. [33] and developed by several groups in the 1990s $[34,35]$, the combination of $90^{\circ}$ coordination building blocks and linear ligands to form square (four metal centers bridged by four equivalent bidentate ligands, Figure 3) and rectangular assemblies (four metal centers bridged by ligands of different lengths) has been widely explored.

A few years later, the same approach was used to generate discrete three-dimensional assemblies [36-38]. So far, a multitude of two- and three-dimensional structures incorporating transition metals with square-planar geometry have been synthesized $[34,39]$. These molecular boxes have been used to generate confined environments to encapsulate guest molecules, to protect sensitive or unstable molecules, to recognize and trap specific guest molecules, or to act as microreactors for specific reactions [32].

Recently, dipalladium(II) molecular cages of the formula $\left[\mathrm{Pd}_{2} \mathrm{~L}_{4}\right](\mathrm{X})_{4}(\mathrm{~L}=2,6$-bis(pyridin-3-ylethynyl)pyridine; $\mathrm{X}=$ $\mathrm{BF}_{4}{ }^{-}$or $\mathrm{SbF}_{6}{ }^{-}$) have been shown to encapsulate two cisplatin molecules within their cavities (Figure 4) [40]. These cages represent the first example of a discrete metalla-assembly encapsulating a FDA-approved inorganic drug molecule. Additionally, the $\left.[\text { (cisplatin })_{2} \subset \mathrm{Pd}_{2} \mathrm{~L}_{4}\right]^{4+}$ host-guest adduct can be quantitatively disassembled upon the addition of a competing ligand, releasing cisplatin in an acetonitrile solution. This property, if extended to biological media, is particularly appealing in the context of drug delivery, as it would potentially enable the controlled release of an encapsulated drug from the metalla-assembly. Unfortunately, the drawback of these palladium assemblies is their lability in water and accordingly their instability in biological media.

The cytotoxic effects of ruthenium compounds are known since the mid-50s [41], but these compounds have mostly remained disregarded, partly because of their poor water solubility, and mostly because the discovery of the anticancer properties of cisplatin in the mid-60s has inclined the research towards platinum compounds. The potential of ruthenium compounds as anticancer drugs has been revived and really exploited only in the mid-80s, with the pioneer work of Clarke on the activation by reduction assumption (Figure 5) [42]. This assumption is based on the generally accepted statement that ruthenium(II) complexes are more reactive than ruthenium(III) complexes. Ruthenium complexes are therefore administered as much less active, nontoxic ruthenium(III) compounds, which are reduced in toxic ruthenium(II) complexes in cancer cells. Only in cancer cells is a chemically reducing environment created, as a result of increased metabolic rate. Scientists working in this field often make a point of comparing ruthenium compounds favorably to platinum compounds in terms of its analogous ligand exchange abilities, lack of cross-resistance, and lower toxicity [43-45].

Currently, two inorganic monoruthenium(III) complexes NAMI-A and KP1019 have shown remarkable activities (Figure 6) [46, 47]. The more water-soluble version of KP1019, 


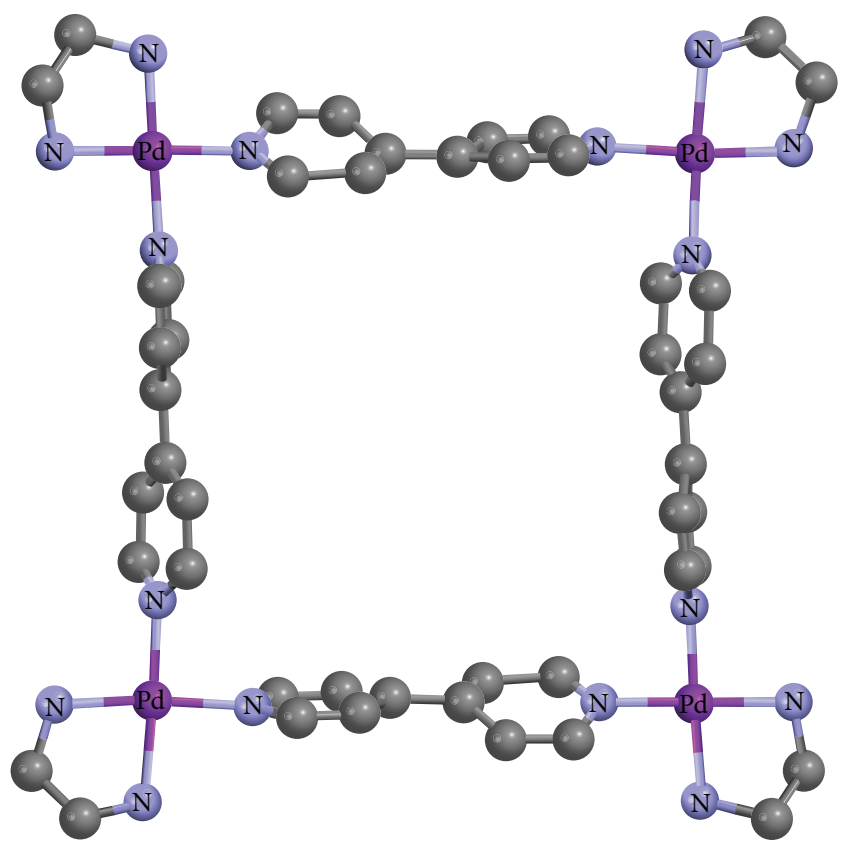

FIgURE 3: First metalla-square obtained by combining $90^{\circ}$ coordination building blocks and linear ligands, adapted from [33].

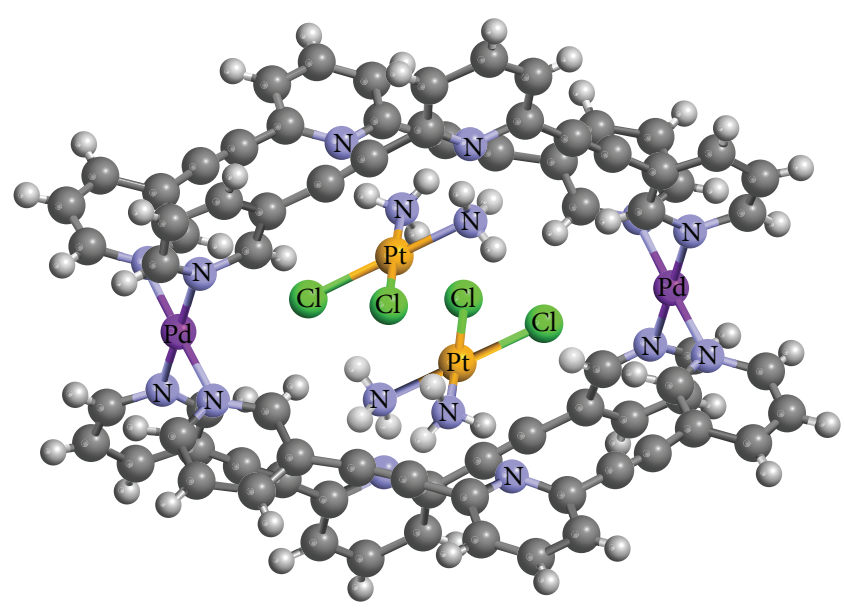

Figure 4: Molecular structure of $\left[(\text { cisplatin })_{2} \subset \mathrm{Pd}_{2} \mathrm{~L}_{4}\right]^{4+}$, adapted from [40].

the sodium salt termed KP1339 (Figure 6), has recently finished a successful clinical phase I trial, where excellent activity, especially against neuroendocrine tumors, was observed [48].

Since the mid-1990s, half-sandwich ruthenium(II) compounds have started to attract considerable attention [49]; in particular, the RAPTA family was developed in the group of Dyson [50-52], and the RM175 and ONCO4417 compounds were developed in the group of Sadler (Figure 7) [53]. These derivatives exhibit very promising characteristics in vitro (RM175) and in vivo (RAPTA). The RAPTA complexes can be considered noncytotoxic in vitro but show antimetastatic activity and have indicated selectivity to cancer cells over nontumor cells [51]. The RAPTA complexes are inactive

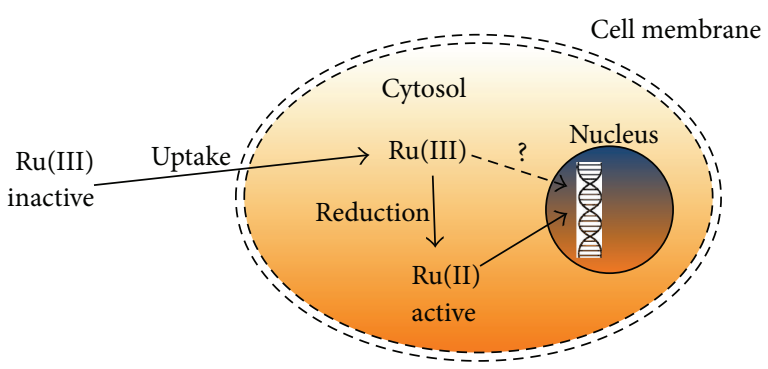

FIGURE 5: Schematic representation of the postulated activation by reduction mechanism, adapted from [42].

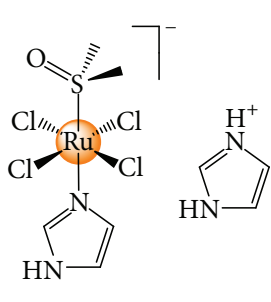

NAMI-A
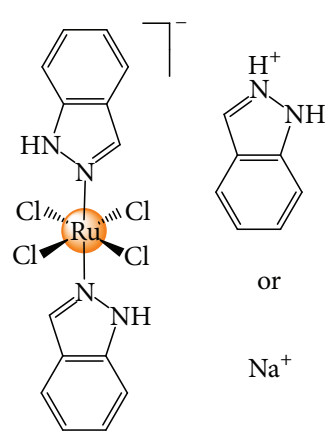

$=\mathrm{KP} 1019$

or

$\mathrm{Na}^{+} \quad=\mathrm{KP} 1339$
FIgURE 6: Molecular structure of the inorganic ruthenium(III) complexes: NAMI-A, KP1019, and KP1339.

against primary tumors, but they appear to reduce the number and weight of metastasis cells. In the case of RM175, it shows high levels of toxicity towards cancer cells, affecting DNA via a parallel interaction, thus resulting in apoptosis [53]. Similarly ONCO4417 was shown to induce apoptosis as well as to halt cell reproduction in various cancer types [53].

As such, arene ruthenium metalla-assemblies have started to attract attention as a potential new class of drug delivery vector. In the following, we will cover some synthetic and structural aspects of arene ruthenium metallaassemblies, as well as their drug delivery potential. To be efficient, metalla-assemblies must exhibit certain stability in order to achieve controlled drug release in the body. In addition, the presence of arene ruthenium building blocks can only be beneficial if selectivity for cancer cells is obtained. A special emphasis has been placed on our contributions to this field over the last years, but important inputs from other groups will be also discussed.

\section{Water-Soluble Arene Ruthenium Complexes}

The water solubility of arene ruthenium complexes is known for 40 years, thanks to Zelonka and Baird who studied the behavior of the benzene ruthenium dichloride dimer in water [54]. Indeed, upon dissolution of [(benzene) $\left.\mathrm{RuCl}_{2}\right]_{2}$ in water, they observed by ${ }^{1} \mathrm{H}$ NMR spectroscopy the formation of aqua species. The complete assignment of the signals was established later [55] but confirmed the observation made by Zelonka and Baird that arene ruthenium dichloride dimers form aqua species in water without rupture of the arene 


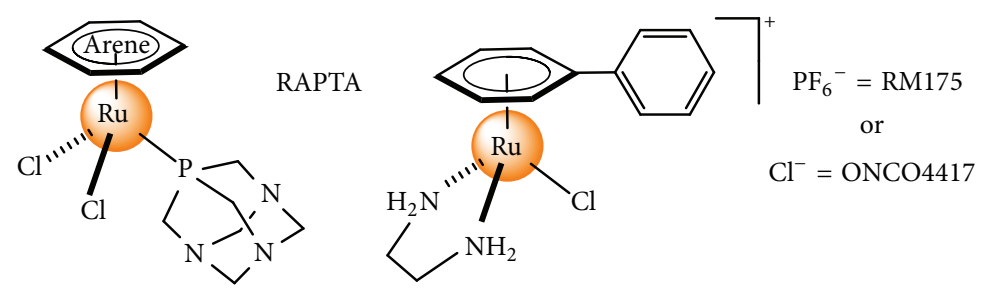

FIGURE 7: Half-sandwich ruthenium(II) complexes: RAPTA, RM175, and ONCO4417.
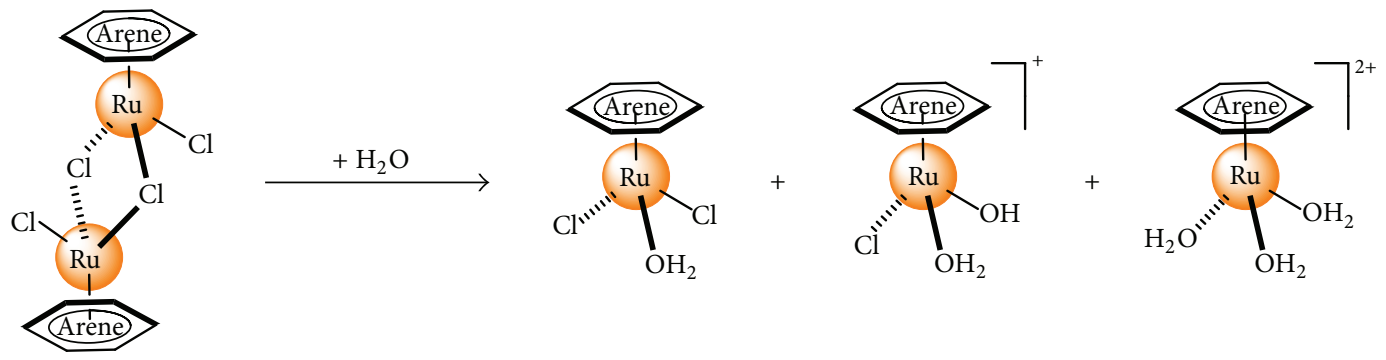

FIgURE 8: Aquation of arene ruthenium dichloride dimers.

ruthenium bond (Figure 8 ). With the stability of the arene ruthenium bond in water being established, the chemistry of arene ruthenium complexes in aqueous solution is now flourishing [55-57].

2.1. Water-Soluble Arene Ruthenium Metalla-Rectangles. The first arene ruthenium metalla-rectangle has been synthesized by Yan et al. in 1997 [58]. It was shown that the dinuclear cation $\left[\{(p \text {-cymene }) \mathrm{Ru}(\mathrm{MeOH})\}_{2}(\mathrm{ox})\right]^{2+}, p$-cymene $=$ $p$-i $\operatorname{PrC}_{6} \mathrm{H}_{4} \mathrm{Me}$, incorporating an oxalato (ox) bridging ligand reacts with $4,4^{\prime}$-bipyridine (bipy) to form in quantitative yield the tetranuclear tetracationic metalla-rectangle $\left[\mathrm{Ru}_{4}(p\right.$ cymene $\left.)_{4}(\text { ox })_{2}(\text { bipy })_{2}\right]^{4+}$ (Figure 9$)$. For ten years, this simple strategy to form metalla-assemblies did not find much attention; however, it is now one of the methods of choice to form arene ruthenium metalla-assemblies, and it remains a milestone in the field.

In 2009, two groups independently prepared watersoluble arene ruthenium metalla-rectangles in view of evaluating them as anticancer agents $[59,60]$. Navarro and Barea have combined hoxonato dinuclear $p$-cymene ruthenium clips with bipy and phen (phen $=4,7$-phenanthroline), while Therrien and his coworkers have used various arenes ( $p$-cymene and hexamethylbenzene), two different bridging ligands (2,5-dihydroxy-1,4-benzoquinonato $=$ dhbq; 2,5 dichloro-1,4-benzoquinonato $=$ dcbq), with bipy and bpe (bpe $=1,2$-bis(4-pyridyl)ethylene), to obtain analogous structures. In both series, the tetracationic metalla-rectangles were found to be cytotoxic in vitro, showing activity in the $\mu \mathrm{M}$ range against ovarian cancer cell lines. In addition, strong interaction with DNA was demonstrated for the hoxonato derivatives, thus confirming the biological relevance of arene ruthenium metalla-assemblies [59].

Following these first studies, Chi, Stang and coworkers have reported several analogous metalla-rectangles, each

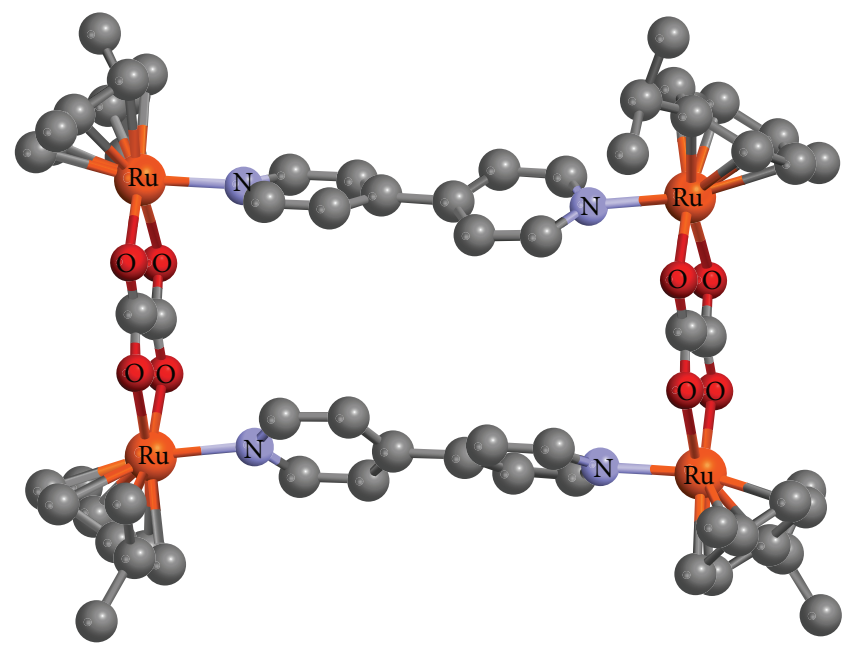

FIGURE 9: Molecular structure of the first arene ruthenium metallarectangle, $\left[\mathrm{Ru}_{4}(p \text {-cymene })_{4}(\mathrm{ox})_{2}(\text { bipy })_{2}\right]^{4+}$, adapted from [58].

being formed by combining dinuclear arene ruthenium clips and bipyridyl connectors $[39,61-65]$. The $\mathrm{IC}_{50}$ values for particular combinations of clips and connectors are in the lower micromolar range, while others show poor activities. However, at this stage, the parameters dictating the biological activity of these metalla-rectangles remain unclear. It has been suggested that the size and the nature of the connectors are important factors, as well as the charge and lipophilicity of the assembly [66]; however, replacing the arene ruthenium units by other half-sandwich complexes showed almost no impact on the activity $[67,68]$. Clearly, these studies suggest that the best combination of arenes, metals, and connectors has yet to be found. 
2.2. Water-Soluble Arene Ruthenium Metalla-Prisms and Metalla-Cubes. In parallel to the development of metallarectangles, three-dimensional metalla-assemblies have been prepared following the same strategy [32], simply by replacing the bidentate connectors by tridentate or tetradentate ligands. For example, combining oxalato bridged dinuclear clips with tridentate 2,4,6-tris(pyridine-4-yl)-1,3,5-triazine (tpt) panels affords in excellent yield the metalla-prism $\left[\mathrm{Ru}_{6}(p-\right.$ cymene $\left.)_{6}(\mathrm{ox})_{3}(\mathrm{tpt})_{2}\right]^{6+}$ (Figure 10), which was isolated as its triflate salt [69]. Similarly, the octanuclear octacationic metalla-cube, $\left[\mathrm{Ru}_{8}(p \text {-cymene })_{8}(\mathrm{ox})_{4}(\mathrm{tpp})_{2}\right]^{8+}$, was obtained by combining oxalato bridged dinuclear clips with $5,10,15,20$ tetra(pyridin-4-yl)porphyrin (tpp) tetradentate panels [70]. Throughout the paper, metalla-prisms are defined as six metal centers connected by two tridentate panels and three bridging ligands, while metalla-cubes are defined as eight metal centers connected by two tetradentate panels and four bridging ligands.

Despite possessing a small cavity, with the $\mathrm{Ru} \cdots \mathrm{Ru}$ separation within these diruthenium oxalato clips being $5.5 \AA$, no guest molecules fit in the cavity of the metalla-prism $\left[\mathrm{Ru}_{6}(p-\right.$ cymene $\left.)_{6}(\mathrm{ox})_{3}(\mathrm{tpt})_{2}\right]^{6+}$ due to strong $\pi$-stacking interactions between the adjacent tpt panels. Therefore, a longer metal $\cdots$ metal distance was needed to allow metalla-prisms and metalla-cubes to encapsulate guest molecules. In large three-dimensional assemblies, a cavity capable of accommodating guest molecules does not necessarily insure host-guest chemistry: access to the cavity is critical for the host-guest process to take place. Therefore, unless the assembly possesses the ability to assemble-disassemble at will in solution, a sufficient portal size of the host is an essential feature [32].

2.3. Stabilization of the G-Quadruplex DNA Formation Using Metalla-Cubes. In 2009, we have shown that arene ruthenium metalla-cubes $\left[\mathrm{Ru}_{8}\left(\eta^{6} \text {-arene }\right)_{8}(\text { tpp- } \mathrm{M})_{2}\right.$ $\left.(\mathrm{dhbq})_{4}\right]^{8+}$ (arene $=$ toluene, $p$-cymene, hexamethylbenzene) (Figure 11), connected by two 5,10,15,20-tetra(4-pyridyl) porphyrin (tpp-2H)or 5,10,15,20-tetra(4-pyridyl) porphyrin$\mathrm{Zn}$ (II) (tpp-Zn) tetrapodal subunits, bind strongly to telomeric and $c-m y c$ DNA. Their selectivity for quadruplex over duplex DNA is very modest. This is likely a consequence of the octacationic nature of the cubes, which will increase their nonspecific binding to DNA via electrostatic interactions. However, these arene ruthenium metalla-cubes provide an interesting new family of complexes to stabilize quadruplex DNA [71].

\section{Encapsulation of Guest Molecules and Host-Guest Properties}

3.1. Encapsulation of Guest Molecules with Metalla-Rectangles. The ability of the metalla-rectangles $\left[\mathrm{Ru}_{4}(p\right.$ cymene $\left.)_{4}(\mathrm{NnN})_{2}(\mathrm{dhnq})_{2}\right]^{4+} \quad\left(\mathrm{N} \cap \mathrm{N}=\right.$ pyrazine, $4,4^{\prime}-$ bipyridine, and 1,2-bis(4-pyridyl)ethylene; dhnq = 5,8-dihydroxy-1,4-naphthoquinonato) to host pyrene in solution has been investigated (Figure 12) [72]. In the case of the smallest metalla-rectangle $\left[\mathrm{Ru}_{4}(p \text {-cymene })_{4}(\text { pyrazine })_{2}(\mathrm{dhnq})_{2}\right]^{4+}$,

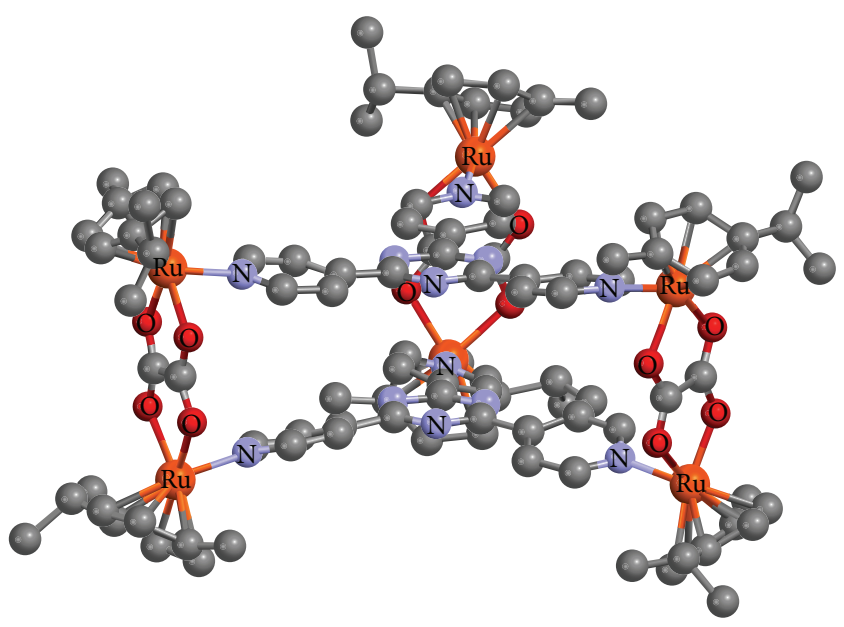

FIgURE 10: Molecular structure of the arene ruthenium metallaprism, $\left[\operatorname{Ru}_{6}(p \text {-cymene })_{6}(\mathrm{ox})_{3}(\mathrm{tpt})_{2}\right]^{6+}$, adapted from [58].

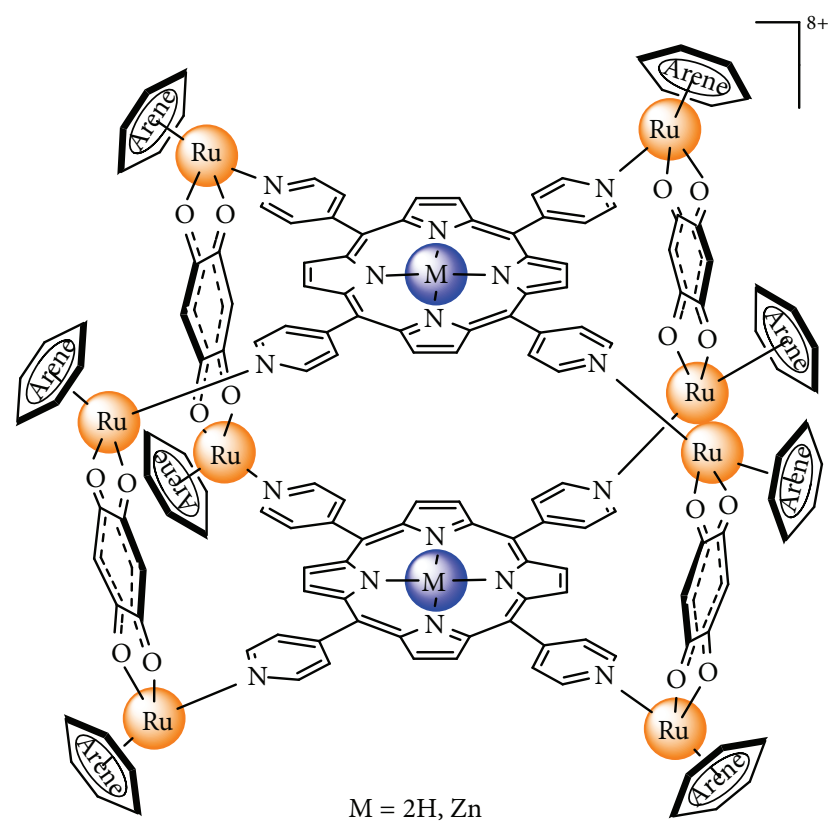

FIGURE 11: Molecular structure of the arene ruthenium metallacubes, $\left[\mathrm{Ru}_{8}\left(\eta^{6} \text {-arene }\right)_{8}(\mathrm{tpp}-\mathrm{M})_{2}(\mathrm{dhbq})_{4}\right]^{8+}$, adapted from [71].

no interaction between the metalla-rectangle and pyrene was observed. However, in the case of the medium-sized metallarectangle $\left[\operatorname{Ru}_{4}(p \text {-cymene })_{4}\left(4,4^{\prime} \text {-bipyridine }\right)_{2}(\mathrm{dhnq})_{2}\right]^{4+}$, interactions occurred on the outside of the rectangular assembly, while in the larger metalla-rectangle $\left[\mathrm{Ru}_{4}(p\right.$ cymene $\left.)_{4}(1,2 \text {-bis(4-pyridyl)ethylene })_{2}(\mathrm{dhnq})_{2}\right]^{4+}$, the pyrene molecule was found inside the hydrophobic cavity of the metalla-rectangle, thus giving rise to a host-guest system.

During this study, we exploited two-dimensional ${ }^{1} \mathrm{H}$ DOSY NMR experiments to gain further insight into the nature of the interactions involved between pyrene and the metalla-rectangles. Diffusion-ordered spectroscopy (DOSY) is a well-established NMR technique that allows separating 


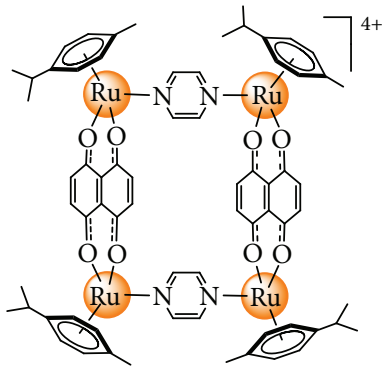

(a)

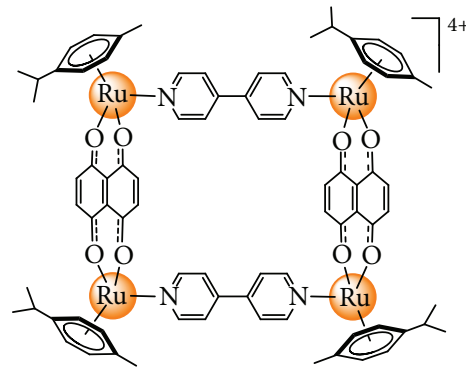

(b)

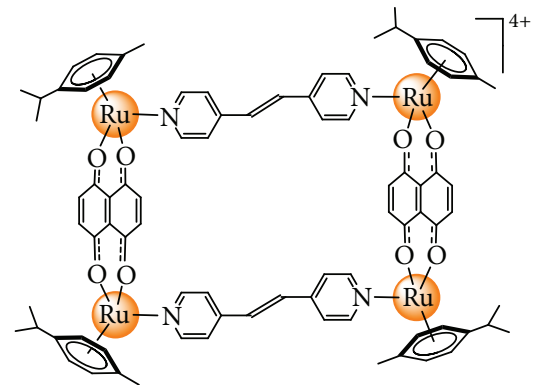

(c)

FIGURE 12: Molecular structure of the arene ruthenium metalla-rectangles, $\left[\operatorname{Ru}_{4}(p \text {-cymene })_{4}(\text { pyrazine })_{2}(\mathrm{dhnq})_{2}\right]^{4+}(\mathrm{a}), \quad\left[\mathrm{Ru} \mathrm{u}_{4}(p-\right.$ cymene $\left.)_{4}\left(4,4^{\prime} \text {-bipyridine }\right)_{2}(\mathrm{dhnq})_{2}\right]^{4+}(\mathrm{b})$, and $\left[\mathrm{Ru}_{4}(p \text {-cymene })_{4}(1,2 \text {-bis }(4 \text {-pyridyl }))(\text { ethylene })_{2}(\mathrm{dhnq})_{2}\right]^{4+}(\mathrm{c})$, adapted from [72].

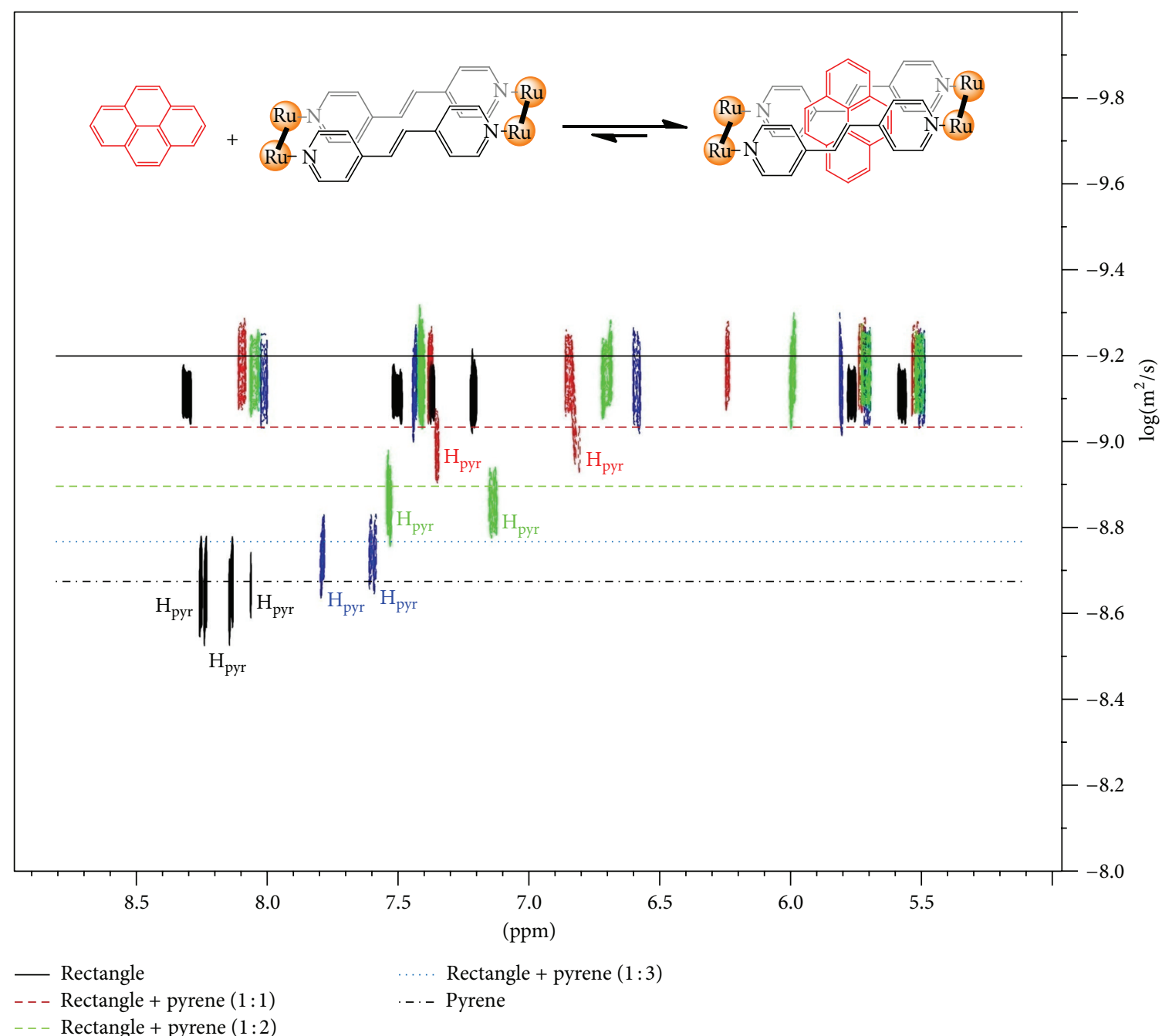

FIGURE 13: DOSY ${ }^{1} \mathrm{H}$ NMR spectra of pyrene, of the metalla-rectangle $\left[\mathrm{Ru}_{4}(p \text {-cymene })_{4}\left(1,2 \text {-bis }(4 \text {-pyridyl)ethylene })_{2}(\mathrm{dhnq})_{2}\right]^{4+}\right.$, and of additional amounts of pyrene (1 to 3 equivalent) to a $4.0 \mathrm{mM}$ solution of $\left[\mathrm{Ru}_{4}(p \text {-cymene })_{4}(1,2 \text {-bis }(4 \text {-pyridyl }) \text { ethylene })_{2}(\mathrm{dhnq})_{2}\right]^{4+}$ dissolved in $\mathrm{CD}_{3} \mathrm{CN}$, adapted from [72]. 
the NMR signals of different species according to their diffusion coefficient [73, 74]. From the DOSY spectra, it is evidenced that the diffusion constants of pyrene and of the medium-sized metalla-rectangle $\left[\mathrm{Ru}_{4}(p \text {-cymene })_{4}\left(4,4^{\prime}\right.\right.$ bipyridine $\left.)_{2}(\mathrm{dhnq})_{2}\right]^{4+}$ are unaffected, when mixed together. Therefore, the chemical shifts observed for the host and the guest were attributed to outer interactions. On the other hand, in the case of the larger metalla-rectangle $\left[\mathrm{Ru}_{4}(p\right.$ cymene $\left.)_{4}(1,2 \text {-bis(4-pyridyl)ethylene })_{2}(\mathrm{dhnq})_{2}\right]^{4+}$, the interaction with pyrene is totally different. The DOSY spectra show that for a 1:1 mixture of pyrene and $\left[\mathrm{Ru}_{4}(p-\right.$ cymene $\left.)_{4}(1,2 \text {-bis(4-pyridyl) ethylene })_{2}(\text { dhnq })_{2}\right]^{4+}$ both diffusion coefficients are almost equivalent at about $6.3 \times$ $10^{-10} \mathrm{~m}^{2} \cdot \mathrm{s}^{-1}$ (Figure 13). Consequently, the pyrene appears to be located in the hydrophobic cavity of $\left[\mathrm{Ru}_{4}(p \text {-cymene })_{4}(1,2-\right.$ bis(4-pyridyl)ethylene $\left.)_{2}(\mathrm{dhnq})_{2}\right]^{4+}$, which is in accordance with the strong chemical shift observed for both species in the ${ }^{1} \mathrm{H}$ NMR spectra.

We have subsequently extended this first study to three other guest molecules, anthracene, perylene, and coronene, and used 9,10-dihydroxy-1,4-anthraquinonato (dhaq) and 6,11-dihydroxynaphthacene-5,12-dionato (dhtq) bridging ligands in addition to 5,8-dihydroxy-1,4-naphthoquinonato (dhnq) [75]. As observed with the metalla-rectangles $\left[\mathrm{Ru}_{4}(p-\right.$ cymene $)_{4}$ (pyrazine $\left.)_{2}(\mathrm{dhnq})_{2}\right]^{4+},\left[\mathrm{Ru}_{4}(p \text {-cymene })_{4}\left(4,4^{\prime}\right.\right.$-bipyridine $\left.)_{2}(\mathrm{dhnq})_{2}\right]^{4+}, \quad$ and $\left[\mathrm{Ru}_{4}(p \text {-cymene })_{4}(1,2\right.$-bis $(4-$ pyridyl) ethylene $\left.)_{2}(\mathrm{dhnq})_{2}\right]^{4+}$, the largest metalla-rectangles incorporating 1,2-bis(4-pyridyl) ethylene linkers are able to host an anthracene, pyrene, perylene, or coronene molecule in their cavity, while the medium-sized metalla-rectangles incorporating $4,4^{\prime}$-bipyridine linkers are only able to encapsulate anthracene. However, out-of-cavity interactions are observed between these $4,4^{\prime}$-bipyridine-containing metalla-rectangles and pyrene, perylene, or coronene. In contrast, the small pyrazine-containing metalla-rectangles showed no interaction in solution with this series of planar aromatic molecules. Using the largest metalla-rectangles, the stability constants of association are comprised between $5.2 \times 10^{4}$ and $6.9 \times 10^{4} \mathrm{M}^{-1}$ which implies a strong affinity between the metalla-rectangle and the aromatic molecule but suggests no selectivity by the metalla-rectangle among these guests.

3.2. Encapsulation of Guest Molecules with Metalla-Prisms and Metalla-Cubes. As demonstrated with the metallarectangles, the presence of a cavity cannot warrant encapsulation of guest molecules. This is also true with metallaprisms and metalla-cubes. Indeed, the smallest metallaprism capable of encapsulating guest molecules was $\left[\mathrm{Ru}_{6}(p-\right.$ cymene $\left.)_{6}(\mathrm{tpt})_{2}(\mathrm{dhbq})_{3}\right]^{6+}$ with a $\mathrm{Ru} \cdots \mathrm{Ru}$ separation of approximately $7.6 \AA$ within the dhbq clip and a $\mathrm{Ru} \cdots \mathrm{Ru}$ separation of approximately $13.2 \AA$ through the tpt panels. This cavity allows the encapsulation of triphenylene derivatives such as hexahydroxytriphenylene and hexamethoxytriphenylene, thus forming carceplex systems [76]. During these studies, we showed for the first time that the formation of these carceplex systems can easily be monitored by one-dimensional ${ }^{1} \mathrm{H}$-ROESY NMR experiments. Using the ROESY experiment, estimation of the different hostguest $\mathrm{H} \cdots \mathrm{H}$ separations could be established from the NMR data and the $\mathrm{H} \cdots \mathrm{H}$ distances found by NMR were in good agreement with the values obtained by single-crystal X-ray structure analysis [76].

In 2008, we reported the ability of the ruthenium metallaprisms $\quad\left[\mathrm{Ru}_{6}(p \text {-cymene })_{6}(\mathrm{tpt})_{2}(\mathrm{dhbq})_{3}\right]^{6+}, \quad\left[\mathrm{Ru}_{6}(p\right.$-cymene $\left.)_{6}(\mathrm{tpt})_{2}(\mathrm{dchq})_{3}\right]^{6+}, \quad\left[\mathrm{Ru}_{6}\left(\mathrm{C}_{6} \mathrm{Me}_{6}\right)_{6}(\mathrm{tpt})_{2}(\mathrm{dhbq})_{3}\right]^{6+}$, and $\left[\mathrm{Ru}_{6}\left(\mathrm{C}_{6} \mathrm{Me}_{6}\right)_{6}(\mathrm{tpt})_{2}(\mathrm{dchq})_{3}\right]^{6+}$ to permanently encapsulate square planar complexes and aromatic molecules [77] (Figure 14). The assembly could be achieved in the presence of large aromatic molecules such as pyrene, fluoranthene, benzo[e]pyrene, triphenylene, or coronene to give the corresponding inclusion systems [arom- aticcprism] ${ }^{6+}$. Interestingly, pyrene could be encapsulated even if it contains a functionalized aliphatic substituent; in this case the aromatic moiety was included in the cage, while the functionalized side arm stood out. These findings opened a simple and straightforward access to the preparation of arene ruthenium metalla-prismatic cages able to encapsulate aromatic and functionalized aromatic molecules, thus demonstrating that they will find applications as drug delivery containers [77].

Subsequently, the capacity to permanently encapsulate large planar molecules as well as to allow host-guest chemistry to take place with smaller aromatic molecules was demonstrated with a slightly more spacious metalla-prism $\left[\mathrm{Ru}_{6}(p \text {-cymene })_{6}(\mathrm{tpt})_{2}(\mathrm{dhnq})_{3}\right]^{6+}$ (Figure 15) [78]. All stability constants of association $(\mathrm{Ka})$ determined by NMR spectroscopy were found to be larger than $2.4 \times 10^{4} \mathrm{M}^{-1}$ for the host-guest systems with pyrene, phenanthrene, and (pyren-1-ylmethyl)amine. On the other hand, using $\mathrm{Pt}(\mathrm{acac})_{2}$ and triphenylene, only carceplexes were obtained.

These studies were extended to two larger cationic metalla-prisms, namely, $\left[\operatorname{Ru}_{6}(p \text {-cymene })_{6}(\mathrm{tpt})_{2}(\mathrm{doaq})_{3}\right]^{6+}$ and $\left[\mathrm{Ru}_{6}(p \text {-cymene })_{6}(\mathrm{tpt})_{2}(\operatorname{dotq})_{3}\right]^{6+}$ (Figure 16$)$. The addition of one equivalent of phenanthrene, pyrene, triphenylene, or coronene during the preparation of the metalla-prism leads to the direct encapsulation of the aromatic molecule [79]. Interestingly, both metalla-prisms exhibited host-guest properties in solution only in the presence of small aromatic molecules (phenanthrene and pyrene). However, for larger aromatic molecules (triphenylene and coronene) capable of fitting into the cavity but too large to exit the portal of the cage, permanent encapsulation was observed, thus giving rise to stable carceplex systems.

\section{Drug Delivery}

4.1. Encapsulation and Release of Bioactive Molecules. The molecular recognition properties coupled with the promising biological activity of ruthenium assemblies suggested that these compounds could potentially act as drug delivery vectors. We have first reported complex-in-a-complex systems, in which platinum or palladium acetyl acetate 


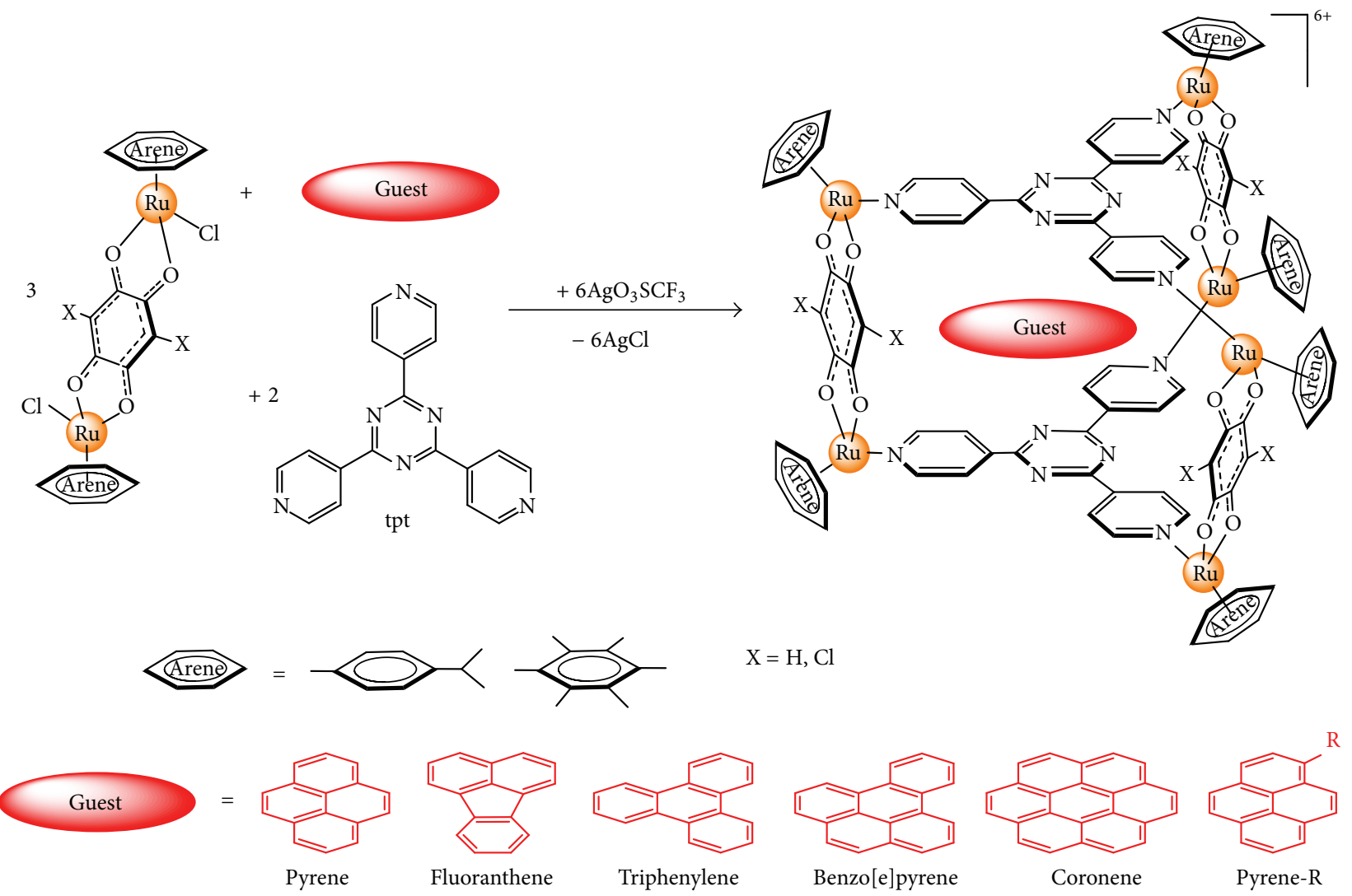

Figure 14: Synthesis of metalla-prisms, $\left[\operatorname{Ru}_{6}(p \text {-cymene })_{6}(\mathrm{tpt})_{2}(\mathrm{dhbq})_{3}\right]^{6+}, \quad\left[\mathrm{Ru}_{6}(p \text {-cymene })_{6}(\mathrm{tpt})_{2}\left(\mathrm{dch}_{\mathrm{C}}\right)_{3}\right]^{6+}, \quad\left[\mathrm{Ru}_{6}(\mathrm{hexamethylben}-\right.$ zene $\left.)_{6}(\mathrm{tpt})_{2}(\mathrm{dhbq})_{3}\right]^{6+}$, and $\left[\mathrm{Ru}_{6}(\text { hexamethylbenzene })_{6}(\mathrm{tpt})_{2}(\mathrm{dchq})_{3}\right]^{6+}$, and molecular structure of the corresponding host-guest systems, adapted from [78].

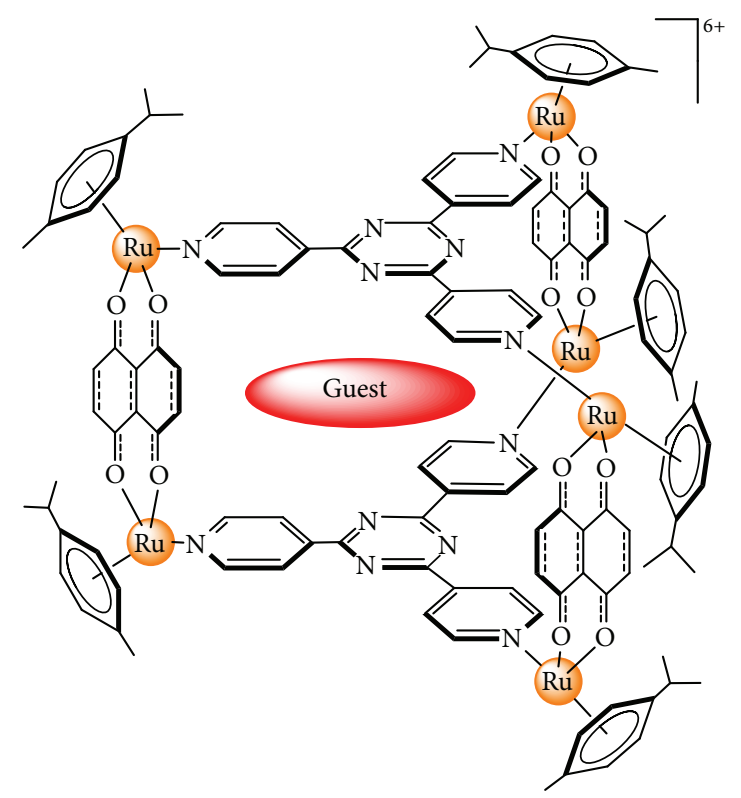

Figure 15: Molecular structure of the metalla-prism $\left[\mathrm{Ru}_{6}(p \text {-cymene })_{6}(\mathrm{tpt})_{2}(\mathrm{dhnq})_{3}\right]^{6+}$, adapted from [79]. 


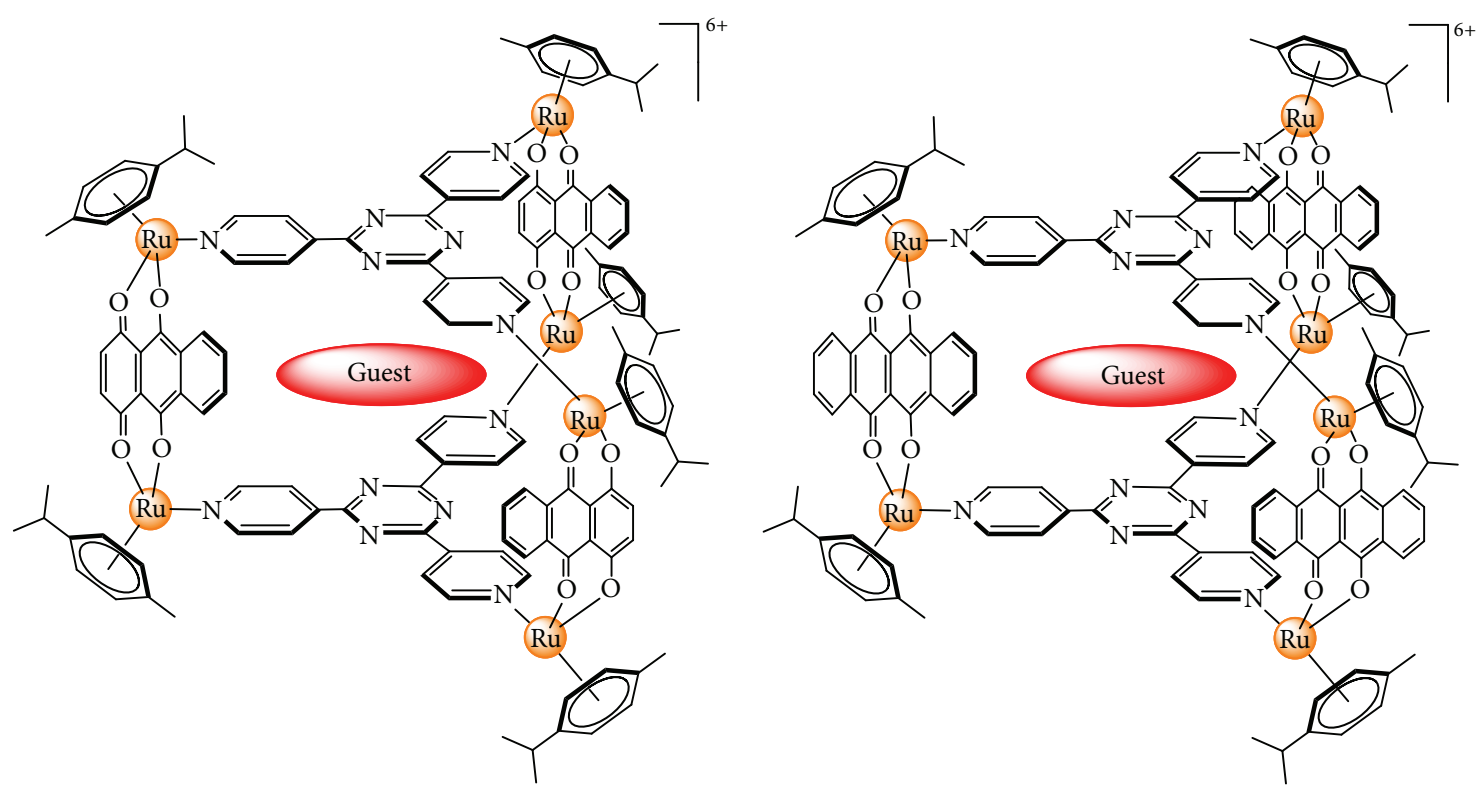

FIGURE 16: Molecular structures of the metalla-prisms $\left[\mathrm{Ru}_{6}(p \text {-cymene })_{6}(\mathrm{tpt})_{2}(\mathrm{doaq})_{3}\right]^{6+}$ and $\left[\mathrm{Ru}_{6}(p-c y m e n e)_{6}(\mathrm{tpt})_{2}(\mathrm{dotq})_{3}\right]^{6+}$, adapted from [80].

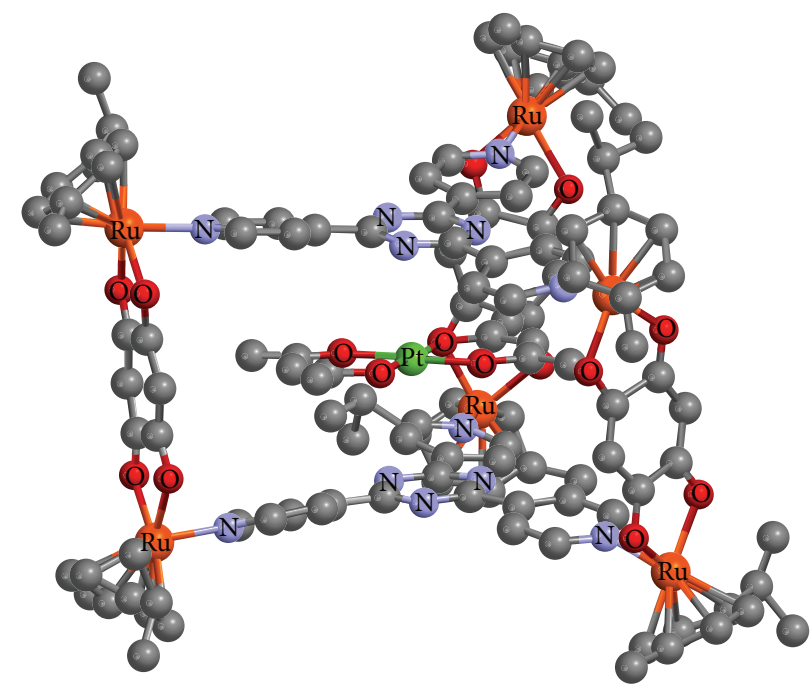

Figure 17: Molecular structure of the complex-in-a-complex system $\left[\mathrm{Pt}(\mathrm{acac})_{2} \subset \mathrm{Ru}_{6}(p \text {-cymene })_{6}(\mathrm{tpt})_{2}(\mathrm{dhbq})_{3}\right]^{6+}$, adapted from $[81]$.

complexes were encapsulated in the cavity of the metallaprism (Figure 17) [80]. The guest complexes by themselves are biologically inactive due to their insolubility in aqueous media. The metalla-prism and host-guest systems, which are on the other hand both water-soluble, are shown to possess high cytotoxic activity [80]. This and subsequent studies to monitor the in vitro release of fluorescent pyrene-based guest molecules, whose fluorescence is suppressed when encapsulated within the metalla-assembly, have shown that the water-soluble metalla-prism is capable of being internalized by cancerous cells and subsequently broken down to release the hydrophobic guest molecules, which would otherwise have been unable to enter the cells [81].

This first success has encouraged us to further investigate these metalla-prisms as drug delivery vectors.
Monosubstituted pyrenyl derivatives were also encapsulated in the metalla-prism $\left[\mathrm{Ru}_{6}(p \text {-cymene })_{6}(\mathrm{tpt})_{2}(\mathrm{dhbq})_{3}\right]^{6+}$ and the drug delivery ability of the resulting hostguests systems was evaluated [81]. The pyrenyl derivatives included biologically relevant structures, especially pyrenyl ethacrynic, a derivate of ethacrynic acid, and 2-(pyren-1ylmethylcarbamoyl) phenyl acetate, the corresponding acid chloride of aspirin (Figure 18). Ethacrynic acid is notably known as an inhibitor of glutathione transferase (GST) $[83,84]$. The host-guest nature of these systems with the pyrenyl moiety being encapsulated in the hydrophobic cavity of the cage with the functional groups pointing outwards was confirmed by NMR spectroscopy. All the host-guest systems are more cytotoxic than the empty cage alone, the most active carceplex being an order of magnitude more 


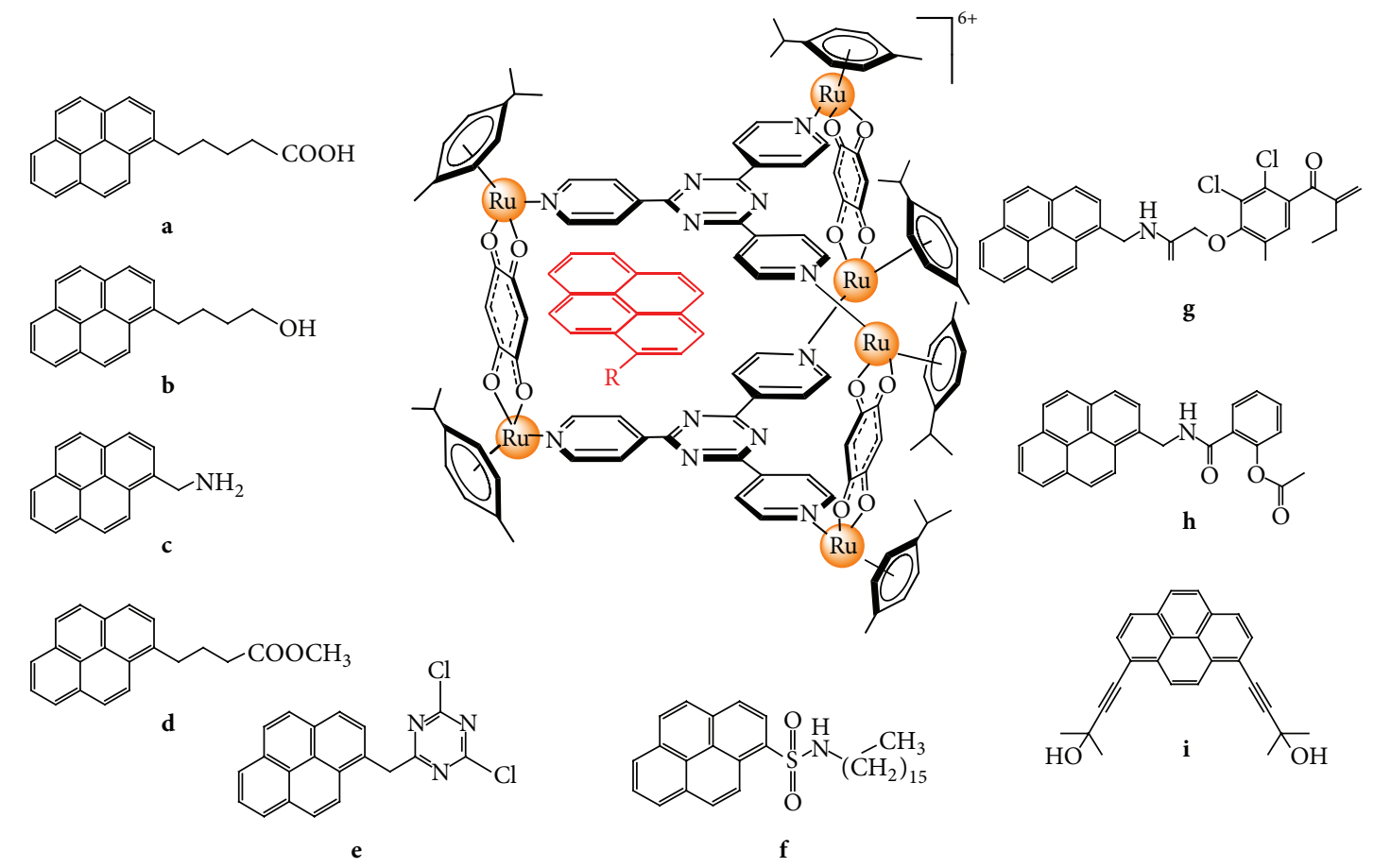

Figure 18: Pyrenyl derivatives encapsulated in the metalla-prism $\left[\mathrm{Ru}_{6}(p \text {-cymene })_{6}(\mathrm{tpt})_{2}(\mathrm{dhbq})_{3}\right]^{6+}(\mathbf{a}=1$-pyrenebutyric acid, $\mathbf{b}$ $=1$-pyrenebutanol, $\mathbf{c}=1$-pyrenemethylamine, $\mathbf{d}=1$-pyrenemethylbutanoate, $\mathbf{e}=1$-(4,6-dichloro-1,3,5-triazin-2-yl) pyrene, $\mathbf{f}=N$ hexadecylpyrene-1-sulfonamide, $\mathbf{g}=$ pyrenyl ethacrynic amide, $\mathbf{h}=2$-(pyren-1-ylmethylcarbamoyl)phenyl acetate) and a disubstituted pyrenyl derivative (i = 1,8-bis(3-methyl-butyn-1-yl-3-ol)pyrene).

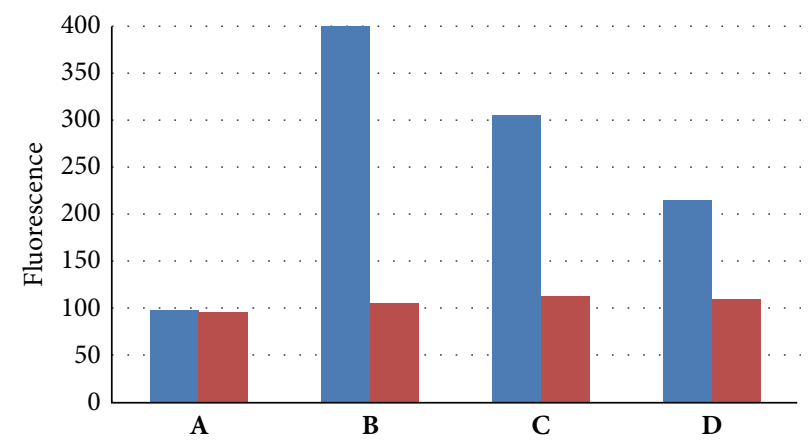

FIGURE 19: Fluorescence recorded by flow cytometry of the metalla-prism $\left[\mathrm{Ru}_{6}(p \text {-cymene })_{6}(\mathrm{tpt})_{2}(\mathrm{dhnq})_{3}\right]^{6+}(\mathbf{A})$ and of 1 -(4,6-dichloro1,3,5-triazin-2-yl)pyrene encapsulated in the metalla-prisms $\left[\mathrm{Ru}_{6}(p \text {-cymene })_{6}(\mathrm{tpt})_{2}\left(\mathrm{dhnq}_{3}\right]^{6+}(\mathbf{B}),\left[\mathrm{Ru}_{6}(p \text {-cymene })_{6}(\mathrm{tpt})_{2}(\mathrm{doaq})_{3}\right]^{6+}(\mathbf{C})\right.$, and $\left[\mathrm{Ru}_{6}(p \text {-cymene })_{6}(\mathrm{tpt})_{2}(\operatorname{dotq})_{3}\right]^{6+}(\mathbf{D})$, indicating pyrene- $\mathrm{R}$ released from the host (blue bars). Ruthenium uptake determined by ICP-MS is also shown (red bars). A2780 cells were incubated with the metalla-prism $\left[\mathrm{Ru}_{6}(p \text {-cymene })_{6}(\mathrm{tpt})_{2}(\mathrm{dhnq})_{3}\right]^{6+}$ and with pyrene-R encapsulated in the three metalla-prisms at $2 \mu \mathrm{m}$ concentration for $24 \mathrm{~h}$, adapted from [82].

cytotoxic. This in vitro study revealed that the nature of the pyrenyl derivative strongly influences the cytotoxicity of the system and consequently confirms that these metalla-cages offer a strategy to deliver biologically relevant molecules to cancer cells [81].

Subsequently, the host-guest properties of a series of larger metalla-prisms $\left[\mathrm{Ru}_{6}(p \text {-cymene })_{6}(\mathrm{tpt})_{2}(\mathrm{dhnq})_{3}\right]^{6+}$, $\left[\mathrm{Ru}_{6}(p \text {-cymene })_{6}(\mathrm{tpt})_{2}(\mathrm{doaq})_{3}\right]^{6+}$, and $\left[\mathrm{Ru}_{6}(p \text {-cymene })_{6}\right.$ $\left.(\mathrm{tpt})_{2}(\mathrm{dotq})_{3}\right]^{6+}$ having similar sized cavities but different portal sizes have been studied [82]. These metalla-prisms are able to encapsulate the fluorescent guest molecule 1-(4,6-dichloro-1,3,5-triazin-2-yl)pyrene (pyrene-R) and the complex $\operatorname{Pd}(\mathrm{acac})_{2}$. Remarkably, the rate of release of the guest molecule is found to depend on the portal size of the host, as shown by flow cytometric analysis of cells incubated with the pyrene- $R$ encapsulated in the three metalla-prisms (Figure 19). It can be seen that the ratio between cell fluorescence and the intracellular ruthenium concentration varies as a function of the metalla-cage used to entrap the pyrene- $\mathrm{R}$ fluorophore.

Nevertheless, the uptake of ruthenium into the cells determined by inductively coupled plasma mass spectroscopy 

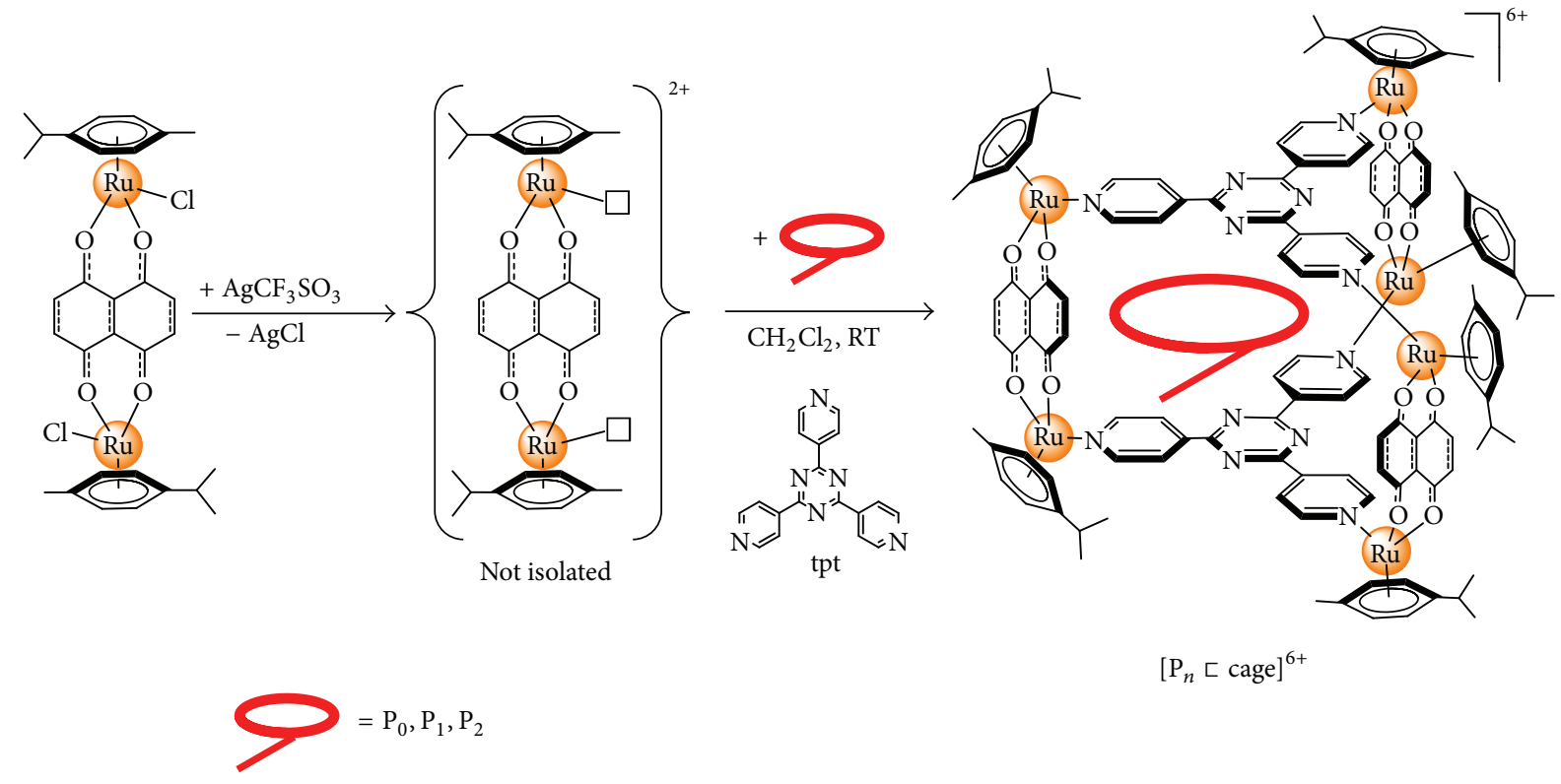

$\left[\mathrm{P}_{n} \sqsubset \text { cage }\right]^{6+}$

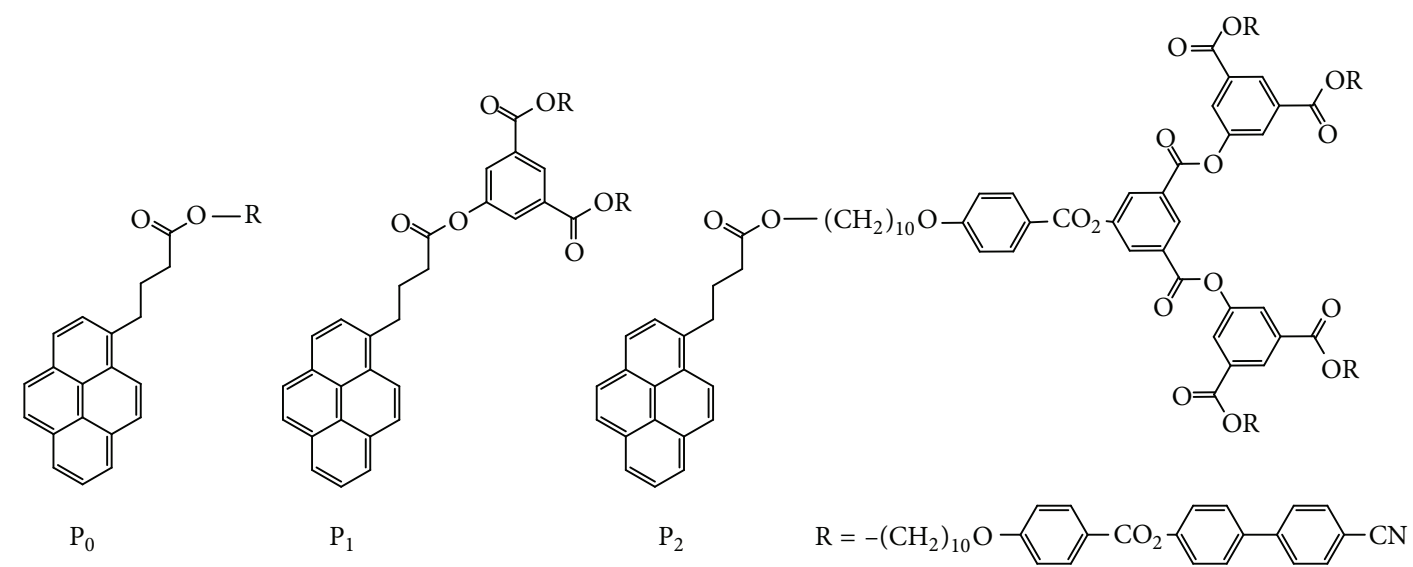

FIGURE 20: Encapsulation of pyrenyl-functionalized dendrimers into the cavity of the metalla-prism $\left[\mathrm{Ru}_{6}(p \text {-cymene })_{6}(\mathrm{tpt})_{2}(\mathrm{dhnq})_{3}\right]^{6+}$.

(ICP-MS) reveals that all compounds enter the cells to essentially the same extent, suggesting a similar uptake mechanism for the three supramolecular complexes. Furthermore, confocal microscopy showed that the pyrene-R stains vesicle like cytoplasmic organelles and accumulates in the intracellular vesicle of the cell endocytotic system. A comparison between the fluorescence patterns of pyrene$\mathrm{R}$ with known fluorescent reporters showed that the free pyrene-R does not enter lysosomal compartments and does not accumulate in the endocytic compartments, which suggest that pyrene- $R$ accumulates in the endocytic rather than the lytic compartments. Through the use of specific inhibitors and fluorescent reporters, we have shown that endocytosis is probably involved in the uptake and leads to the accumulation of the guest molecule in intracellular organelles.

Lately, we have been interested in the synthesis of host-guest systems composed of water-soluble arene ruthenium metalla-prisms and pyrenyl-functionalized dendrimers (Figure 20) [85-87]. Dendrimers with defined structures are well established and have been studied as potential drug delivery vectors [26]. In particular, water-soluble and biodegradable dendrimers are quite promising, as they have been shown to improve drug solubility, to increase drug circulation time, and to prolong drug residence in tumors.

We have first reported the synthesis and cytotoxicity of host-guest systems composed of water-soluble arene ruthenium metalla-prisms and pyrenyl-functionalized dendrimers [86]. These studies showed that the host-guest systems inhibit the growth of both sensitive and cisplatin resistant cancer cells (A2780 and A2780cisR) with IC $_{50}$ values significantly lower than those of the empty metalla-prisms. The dendrimers show no cytotoxic effects on these cell lines, presumably owing to their poor solubility in water. However, for the first time, this study has shown that metalla-cage host systems are able to deliver large hydrophobic guest molecules into cancer cells.

Subsequently, we have synthesized different generations of biodegradable water-soluble dendrimers based on 


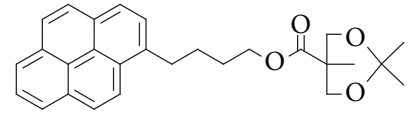

$\mathrm{Pyr}_{\mathrm{G} 1}$

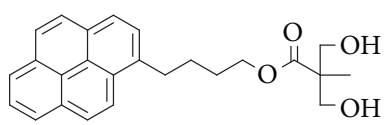

$\mathrm{Pyr}_{\mathrm{G} 1-\mathrm{OH}}$

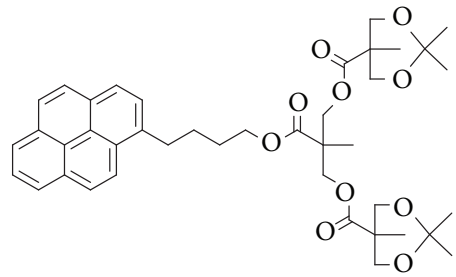

$\mathrm{Pyr}_{\mathrm{G} 2}$

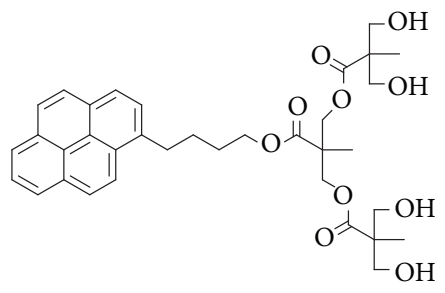

$\mathrm{Pyr}_{\mathrm{G} 2-\mathrm{OH}}$
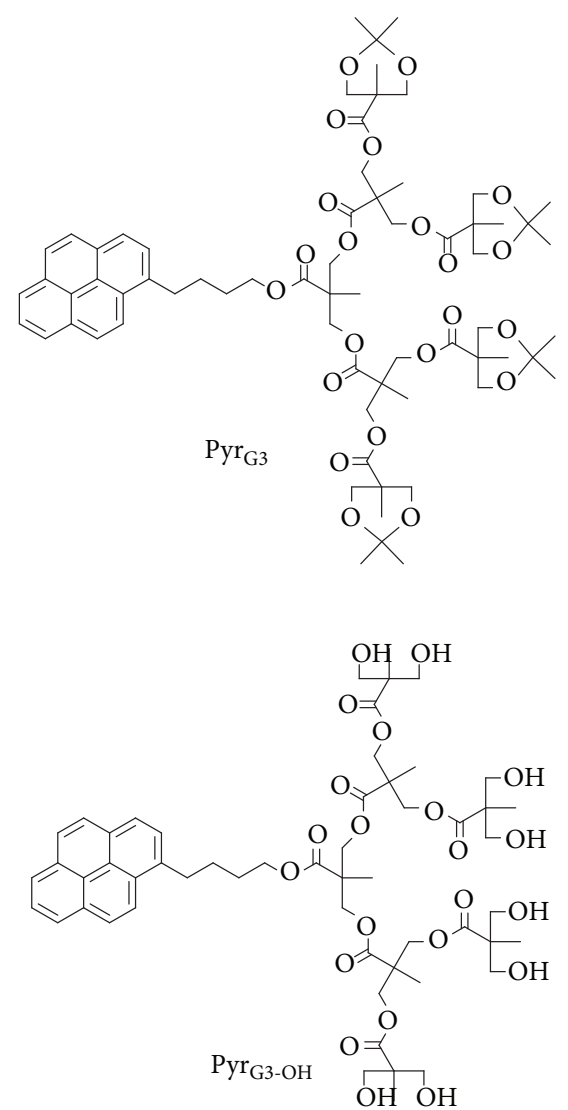

FiguRE 21: Biodegradable water-soluble dendrimers encapsulated in the cavity of the metalla-prisms $\left[\operatorname{Ru}_{6}(p-c y m e n e)_{6}(\mathrm{tpt})_{2}(\mathrm{dhnq})_{3}\right]^{6+}$ and $\left[\mathrm{Ru}_{6}(p \text {-cymene })_{6}(\mathrm{tpt})_{2}(\operatorname{dotq})_{3}\right]^{6+}[85]$.

the bis-MPA monomer functionalized by a pyrenyl unit [87]. The aromatic part of the pyrenyl-functionalized dendrimers could be encapsulated into the hydrophobic cavity of the metalla-prisms $\left[\mathrm{Ru}_{6}(p \text {-cymene })_{6}(\mathrm{tpt})_{2}(\mathrm{dhnq})_{3}\right]^{6+}$ and $\left[\mathrm{Ru}_{6}(p \text {-cymene })_{6}(\mathrm{tpt})_{2}(\text { dotq })_{3}\right]^{6+}$ (Figure 21$)$. Remarkably, the cytotoxicity of the resulting host-guest systems $\left(\mathrm{IC}_{50}\right.$ values ranging from 0.3 to $4.1 \mu \mathrm{M}$ ) was considerably greater than that of the individual hosts ( $\mathrm{IC}_{50}$ values 3.1 and $4.1 \mu \mathrm{M}$ ) and guests $\left(\mathrm{IC}_{50}\right.$ values 5.9 and $\left.8.7 \mu \mathrm{M}\right)$. The enhanced cytotoxicity of the host-guest systems compared to the guest or host alone implies that intact host-guest systems are entering the cells together and are responsible for the overall cytotoxicity observed. Notably, the host-guest system is also quite stable in biological media. These features, combined with the potential of water-soluble dendrimers guests within ruthenium metalla-prism hosts to preferentially accumulate in tumors, make them interesting candidates for further study and development.

4.2. Encapsulation and Release of Photosensitizers. Photodynamic therapy (PDT) of cancer is a very powerful and efficient method to treat diseases $[88,89]$, but the treatment is potentially hampered by several aspects, one of the most problematical being the chemical nature of the photosensitizers [90]. Indeed, photosensitizers such as porphyrins and phthalocyanines are in general poorly water-soluble, unless highly substituted with hydrophilic groups, and exhibit generally a low selectivity for cancer cells.

The development of vector-mediated selective drug delivery strategies is a major challenge in PDT. As such, encapsulation of the photosensitizer within the hydrophobic cavity of water-soluble carriers provides an elegant strategy to transport photosensitizers in aqueous media.

Using the metalla-prism $\left[\mathrm{Ru}_{6}(p \text {-cymene })_{6}(\mathrm{tpt})_{2}\right.$ $\left.(\mathrm{dhnq})_{3}\right]^{6+}$ and a larger octanuclear metalla-cube $\left[\mathrm{Ru}_{8}(p-\right.$ cymene $\left.)(\mathrm{dhnq})_{4}(\mathrm{tpvb})_{2}\right]^{8+}(\mathrm{tbpv}=1,2,4,5$-tetrakis $\{2-(4-$ pyridyl) vinylbenzene) $\}$ (Figure 22), both water-soluble, we could demonstrate that porphin was encapsulated in the metalla-cages and subsequently delivered intracellularly [91-93]. As expected, the release of porphin is higher for the larger cubic cage as compared to the smaller prismatic cage. Interestingly, both systems display hypochromism properties toward the photosensitizer when encapsulated inside the cavity, resulting in the absence of phototoxic effect when inside the cavity. This ability demonstrates that the cages can be considered as powerful tools for new photodynamic strategies.

Subsequently, we have reported an extension of this work by studying the host-guest properties of the metalla-prisms $\left[\mathrm{Ru}_{6}(p \text {-cymene })_{6}(\text { tris-pvb })_{2}(\mathrm{OO} \cap \mathrm{OO})_{3}\right]^{6+}$, 

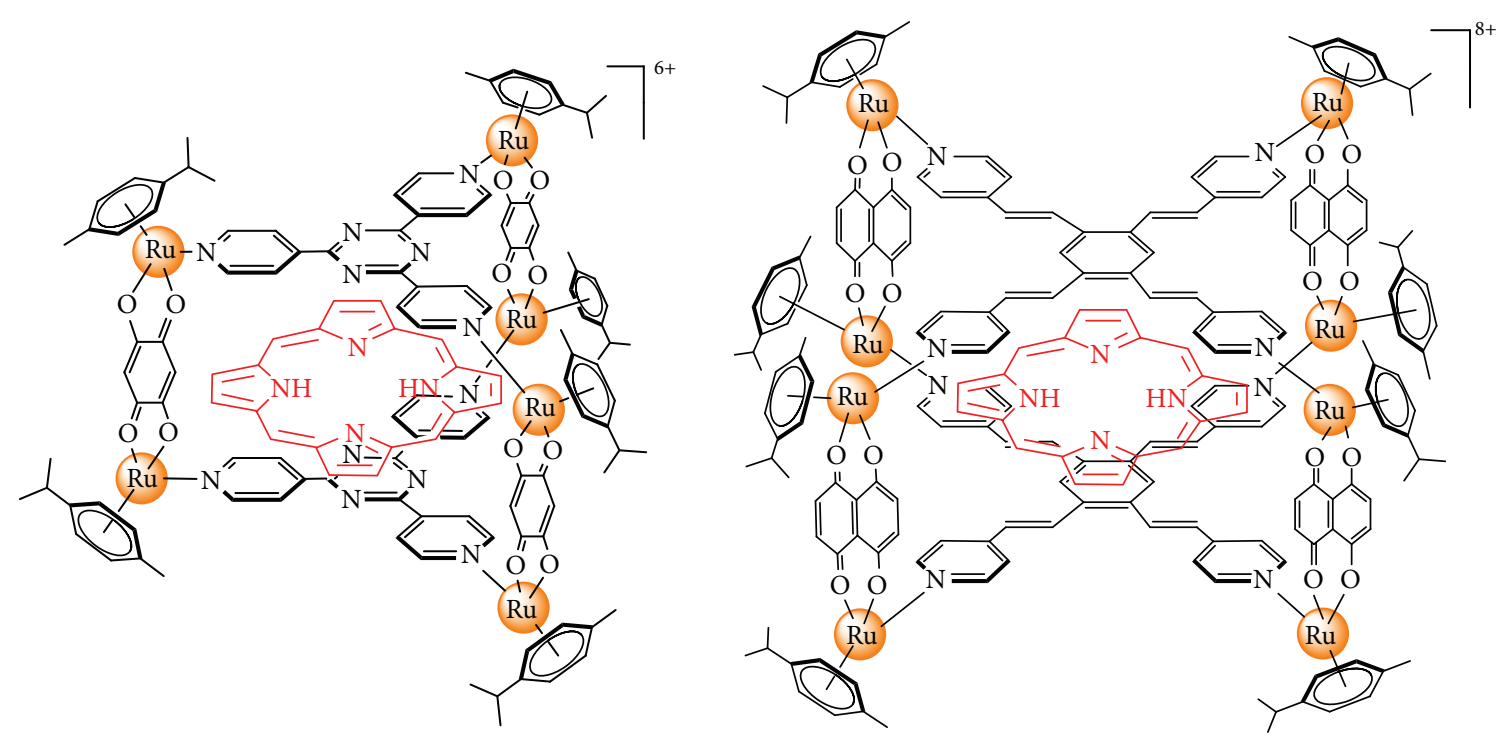

FIGURE 22: Encapsulation of porphin into the cavities of the metalla-prism $\left[\operatorname{Ru}_{6}(p \text {-cymene })_{6}(\mathrm{tpt})_{2}(\mathrm{dhnq})_{3}\right]^{6+}$ and the larger octanuclear metalla-cube $\left[\mathrm{Ru}_{8}(p \text {-cymene })(\mathrm{dhnq})_{4}(\mathrm{tpvb})_{2}\right]^{8+}$.

OOกOO = oxalato, dhbq, dcbq, dhnq, doaq, and donq (Figure 23), and of the metalla-cubes $\left[\mathrm{Ru}_{8}(p\right.$ cymene $\left.)_{8}(\mathrm{NN \cap NN})_{2}(\mathrm{OO \cap OO})_{4}\right]^{8+}(\mathrm{NN \cap NN}=1,2,4,5-$ tetrakis $\{2$-(pyridin-4-yl)vinyl\}benzene, 1,2,4,5-tetrakis $\{2$ (pyridin-4-yl)ethynyl benzene), OOกOO = oxalato, dhbq, dcbq, dhnq, doaq, and donq) (Figure 24) [91]. The photosensitizers porphin, phthalocyanine, and $\mathrm{Zn}$-phthalocyanine present during the synthesis of these metalla-cages are encapsulated in several of these arene ruthenium complexes to give photosensitizer-encapsulated systems. NMR analysis indicates that the guest photosensitizers are completely encapsulated in two of these metalla-cages, while in three other ruthenium cages the NMR spectra reveal an equilibrium between empty and filled metalla-cages.

\section{Reactivity of Arene Ruthenium Metalla-Prisms}

As mentioned in the previous parts, the expected function of these ruthenium metalla-assemblies is the selective release of an encapsulated drug in cancer cells. In principle, carceplexes as well as host-guest systems could be used to achieve this goal. However, both systems have inherent advantages and drawbacks that should be first considered. In carceplex systems, the guest molecule is expected to remain encapsulated in the metalla-assembly until the host-guest system reaches its final target. The drawbacks of carceplex systems are therefore directly related to the stability of the metallaassembly in biological media. If the stability of the metallaassembly is insufficient, the guest molecule will be released in an uncontrolled manner within the human body and at sites where the guest molecule is not necessarily needed, leading potentially to a general toxicity and to undesired side effects. Likewise, if the stability of the metalla-assembly is excessively high, the selective release of an encapsulated drug at the desired sites might last too long or may even never occur if the metalla-assembly remains intact.

The advantages and drawbacks of host-guest systems are similar to those of the carceplex systems, with the additional problem of controlling the exchange rate of the encapsulated molecule. Indeed, if the rate of exchange is too fast, reactions between the encapsulated molecule and the body's molecular components (proteins, amino acids, and lipids) cannot be avoided and most importantly cannot be controlled. Furthermore, because a guest molecule might well react with its surroundings within human bodies, the probability that the guest molecule reenters into the cavity of the metalla-assembly is significantly reduced. On the contrary, if the rate of exchange is too slow, the selective release of an encapsulated drug in cancer cells will be excessively long or even be completely suppressed if the exchange rate approaches zero.

According to our recent findings, it turns out that controlling the exchange rate of a guest molecule encapsulated in a ruthenium metalla-assembly is a demanding task. Indeed, to obtain a suitable exchange rate between the assembly and the guest molecule, that is, to design a host-guest system that would be able to release the target molecule at the desired site and at the desired time interval, a fine tuning of both structures of the metalla-assembly and of the guest molecule is required. For those reasons, we believe that, for selectively releasing an encapsulated drug in cancer cells, carceplex systems appear more appropriate than host-guest systems. Thus, in order to gain new insights into uptake, release of the guest, and the other biological processes, we have started to monitor reactions of various ruthenium metalla-prisms with biological targets. Since all host-guest systems studied so far are more cytotoxic than the empty assemblies themselves, these studies were also useful for understanding their possible mechanisms of action. 

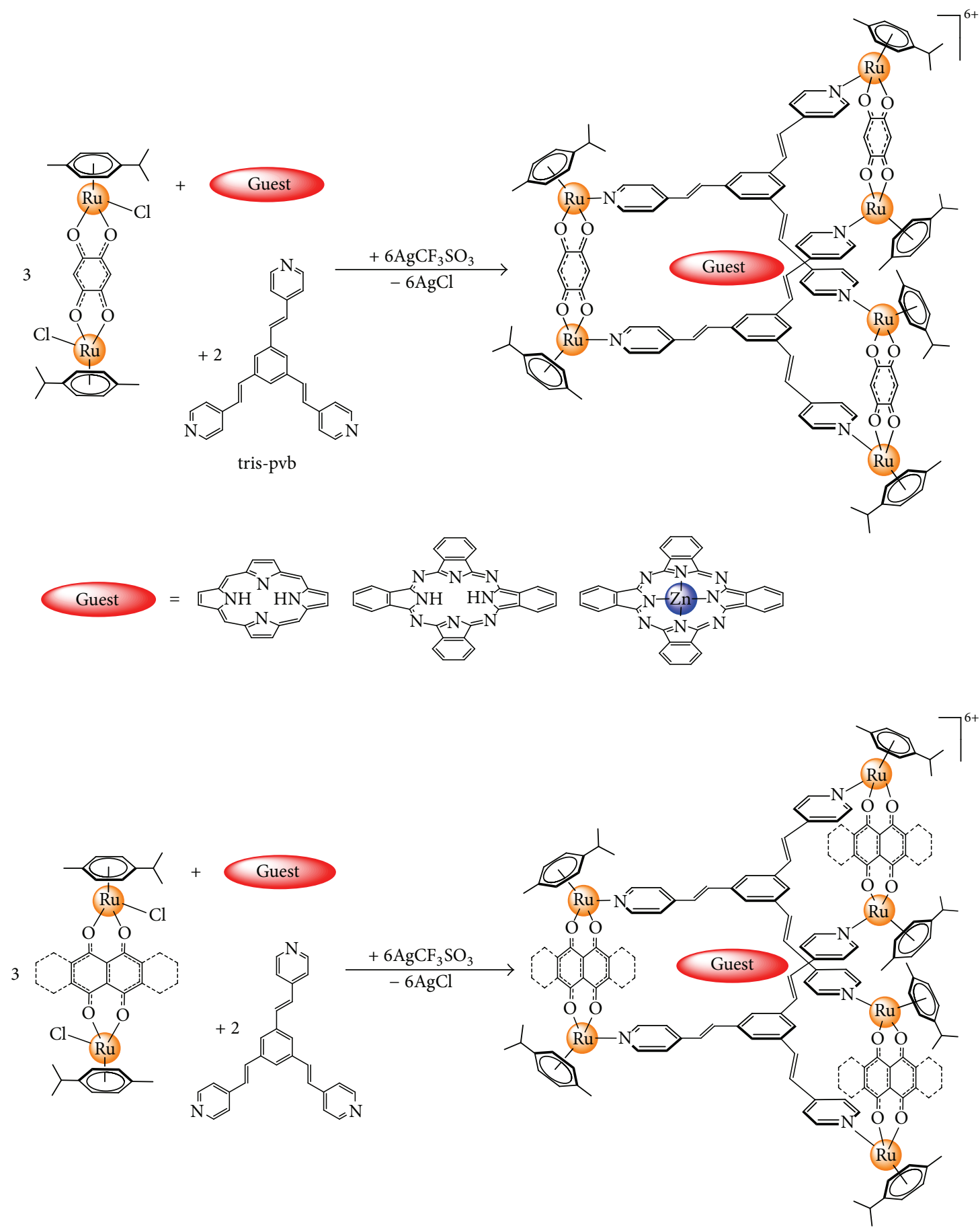

FIGURE 23: Encapsulation of various photosensitizers into the cavities of the metalla-prisms $\left[\mathrm{Ru}_{6}(p-c y m e n e)_{6}(\text { tris-pvb })_{2}\left(\mu_{2}-\mathrm{Cl}\right)_{6}\right]^{6+}$ and $\left[\mathrm{Ru}_{6}(p \text {-cymene })_{6}(\text { tris-pvb })_{2}(\mathrm{OO \cap OO})_{3}\right]^{6+}, \mathrm{OO \cap OO}=$ oxalato, dhbq, dcbq, dhnq, doaq, and donq, adapted from [94].

5.1. Reactivity against Amino Acids and Proteins. Various experiments were undertaken in our groups to establish the nature of the species that are effectively transported into the cell, possible mechanisms of detoxification, and further information on the cellular target that may be related to the antitumor activity of the metalla-prisms. Our first results showed that the metalla-prism $\left[\mathrm{Ru}_{6}(p-\right.$ cymene $\left.)_{6}(\mathrm{tpt})_{2}(\mathrm{dhbq})_{3}\right]^{6+}$ specifically interacts with the thiol groups of Cys and GSH and with the basic side chains of His, Lys, and Arg but remains surprisingly inert upon the addition of Met [94]. The results suggest that the reaction of the metalla-prism $\left[\mathrm{Ru}_{6}(p \text {-cymene })_{6}(\mathrm{tpt})_{2}(\mathrm{dhbq})_{3}\right]^{6+}$ with Arg, His, and Lys takes place within a few minutes with quantitative release of the tpt and dhbq ligands. As a plausible mechanism, Arg, His, and Lys may first coordinate to the ruthenium atom via one of the basic groups of the side chain 
4

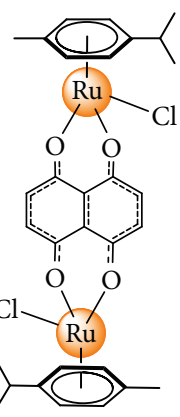

$+$

$\mathrm{N}=$

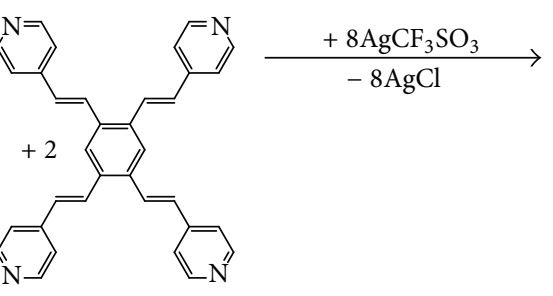

tetra-pvb

\section{Guest}

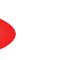

-
Guest

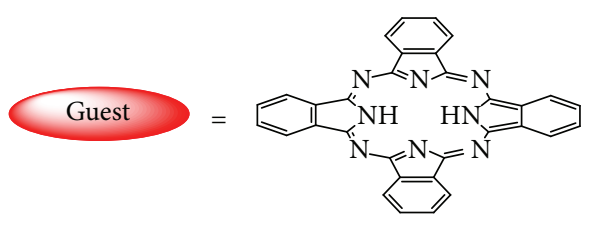

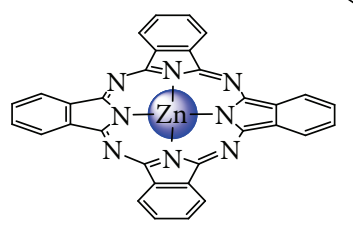
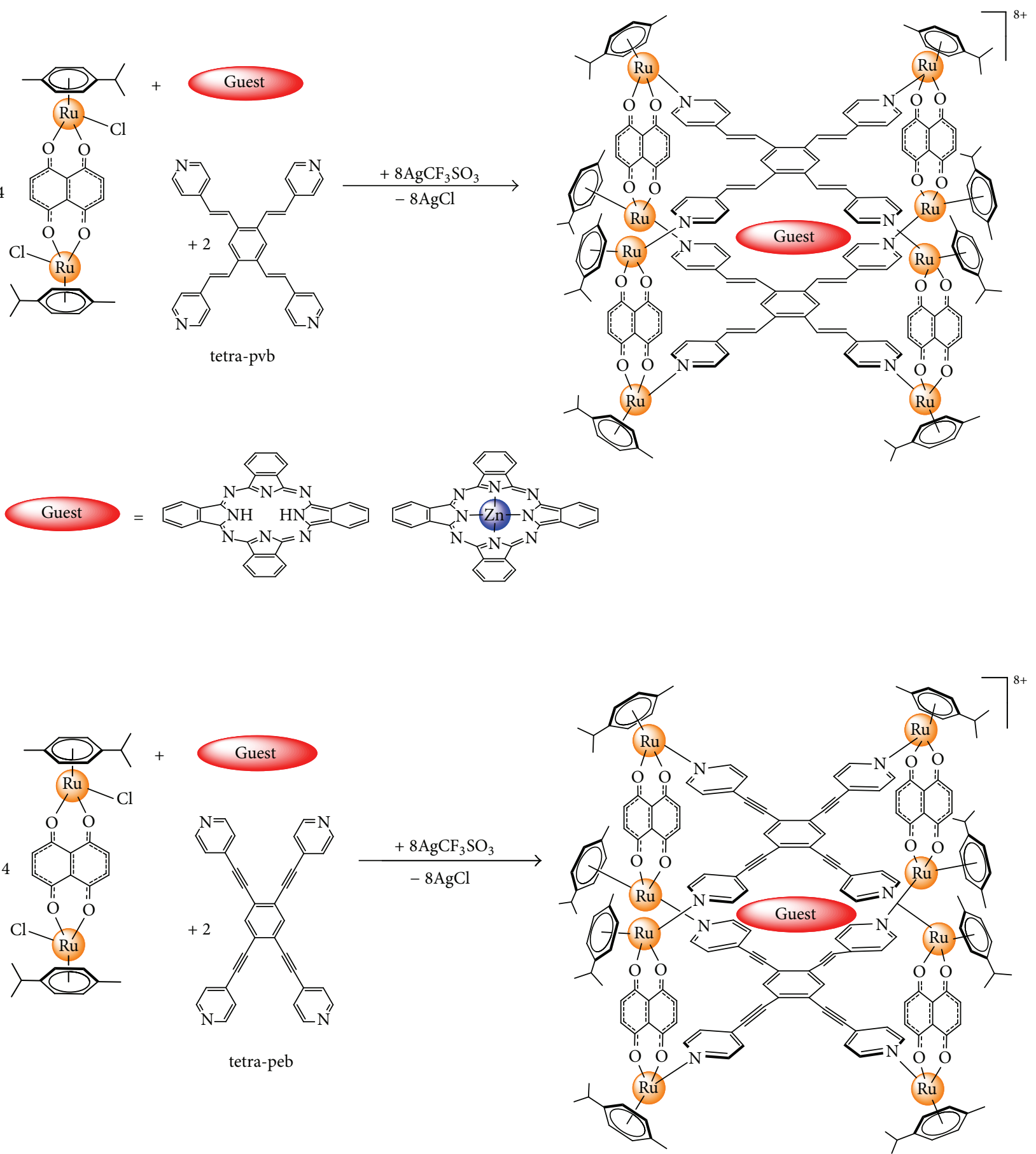

FIGURE 24: Encapsulation of various photosensitizers into the cavities of the cages $\left[\mathrm{Ru}_{8}(p \text {-cymene })_{8}(\mathrm{NN \cap NN})_{2}(\mathrm{OO} \cap \mathrm{OO})_{4}\right]^{8+}, \mathrm{NN} \cap \mathrm{NN}$ $=1,2,4,5$-tetrakis $\{2$-(pyridin-4-yl)vinyl $\}$ benzene, 1,2,4,5-tetrakis $\{2$-(pyridin-4-yl)ethynyl $\}$ benzene), OOกOO $=$ oxalato, dhbq, dcbq, dhnq, doaq, and donq, adapted from [94].

inducing the quantitative release of the tpt moiety. Through this first coordination, the two $\mathrm{Ru}-\mathrm{O}$ bonds between the ruthenium atom and dhbq are released by the carboxylato and the amino groups of the amino acid which can act as second and third ligands, thus forming N,N,O- or N,Ochelate adducts (Figure 25).
Interestingly, the larger metalla-prism $\left[\mathrm{Ru}_{6}(p \text {-cymene })_{6}\right.$ $\left.(\mathrm{tpt})_{2}(\mathrm{dhnq})_{3}\right]^{6+}$ appears to be significantly more stable than the metalla-prism $\left[\mathrm{Ru}_{6}(p \text {-cymene })_{6}(\mathrm{tpt})_{2}(\mathrm{dhbq})_{3}\right]^{6+}$ and is disassembled in the presence of Arg, His, and Lys after $12 \mathrm{~h}$ of incubation [95]. Moreover, the reaction with His was not complete, since only $14 \%$ of His reacted after more than 1 week 


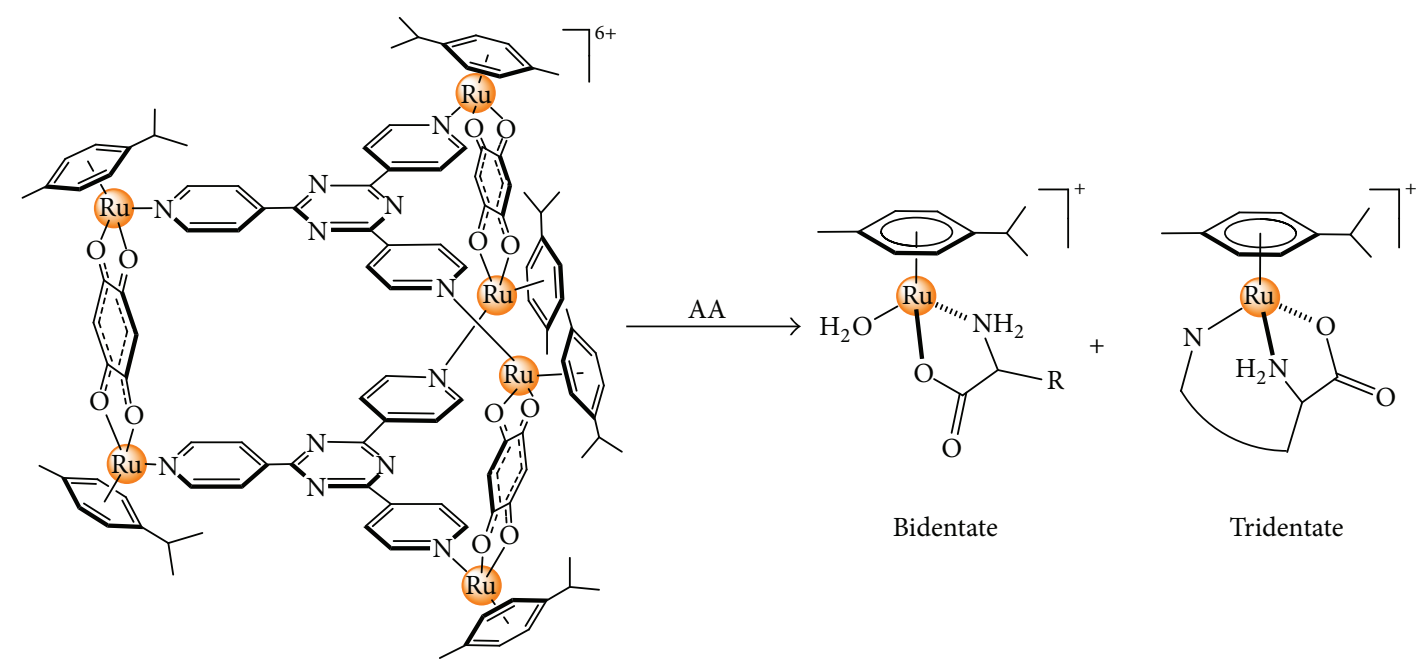

FIGURE 25: Suggested structures of the bi- and tridentate chelate complexes obtained from the reaction of Arg, His, and Lys with the metallaprism $\left[\mathrm{Ru}_{6}(p \text {-cymene })_{6}(\mathrm{tpt})_{2}(\mathrm{dhbq})_{3}\right]^{6+}$ (adapted from [94]).

of incubation. Our results suggest that the metalla-prism $\left[\mathrm{Ru}_{6}(p \text {-cymene })_{6}(\mathrm{tpt})_{2}(\mathrm{dhnq})_{3}\right]^{6+}$ which is more robust than metalla-prism $\left[\mathrm{Ru}_{6}(p \text {-cymene })_{6}(\mathrm{tpt})_{2}(\mathrm{dhbq})_{3}\right]^{6+}$ may remain intact in the bloodstream and, therefore, may enter cancer cells undamaged.

Our results obtained with these ruthenium metallaprisms seem to corroborate a recent study by Hanif et al. [96], which suggests an inverse correlation between metallo-drug protein interaction and cytotoxicity against tumor cells. Indeed, similar to the metalla-prism $\left[\mathrm{Ru}_{6}(p\right.$ cymene $\left.)_{6}(\mathrm{tpt})_{2}(\mathrm{dhnq})_{3}\right]^{6+}\left(\mathrm{IC}_{50}=0.45 \mu \mathrm{M}\right.$ against $\mathrm{A} 2780$ cells), the metalla-prism $\left.\left[\mathrm{Ru}_{6}(p \text {-cymene })_{6}(\mathrm{tpt})_{2} \text { (oxalato }\right)_{3}\right]^{6+}$ $\left(\mathrm{IC}_{50}=0.93 \mu \mathrm{M}\right.$ against $\mathrm{A} 2780$ cells $)$ reacts relatively slowly and incompletely with biomolecules [97]. The less cytotoxic assembly $\left(\mathrm{IC}_{50}=0.96 \mu \mathrm{M}\right.$ against $\mathrm{A} 2780$ cells $),\left[\mathrm{Ru}_{6}(p-\right.$ cymene $\left.)_{6}(\mathrm{tpt})_{2}(\mathrm{dhbq})_{3}\right]^{6+}$, on the other hand, reacts rather quickly with biomolecules, and a complete and fast disassembly could be observed with Arg, His, and Lys.

5.2. Tuning/Controlling the Reactivity. As shown in the previous sections, ruthenium assemblies must exhibit a certain degree of stability, in order to selectively release the encapsulated drug in the cancer cells and not in the cytosol. As discussed, the stability of metalla-assemblies is a central criterion and should be sufficient; otherwise the drug might be released in an uncontrolled manner within the human body. The stability should also not be excessive; otherwise the drug might remain encapsulated and the host-guest system might spread in an uncontrolled manner within the human body.

Our results suggest a connection between the linkers used and the reactivity of the resulting metalla-assembly. To further investigate this hypothesis, studies of other arene ruthenium assemblies bearing bulkier ligands such as hexamethylbenzene instead of $p$-cymene, or ruthenium assemblies with more sterically hindered linkers, are currently undertaken. The possible correlation between reactivity and cytotoxicity for these new arene ruthenium assemblies and their host-guest properties will be investigated in the near future.

\section{Conclusion}

In this review article, strategies applied to obtain tetranuclear metalla-rectangles, hexanuclear metalla-prisms, and octanuclear metalla-cubes and their host-guest properties have been extensively described. As shown along this review, some of these systems show great potential for host-guest chemistry and for biological applications. The straightforward synthetic strategy can be easily exploited and adapted to build up other supramolecular ruthenium assemblies for encapsulating water-insoluble bioactive molecules and photosensitizers. We are further extending this concept to arene-osmium and to rhodium and iridium half-sandwich complexes, to obtain metalla-assemblies with different properties, such as stability, solubility, and charge. We are also working on the synthesis of stimuli-responsive metalla-assemblies. Among external stimuli to initiate the release of guest molecules, we can in particular envisage the use of light, $\mathrm{pH}$, temperature, and chemicals. In conclusion, the encapsulation of guest molecules in watersoluble arene ruthenium metalla-assemblies allows the guest molecule to reach cellular components and organelles that would be otherwise inaccessible and opens new perspectives for scientists.

\section{Conflict of Interests}

The authors declare that there is no conflict of interests regarding the publication of this paper.

\section{Acknowledgments}

Julien Furrer thanks the University of Berne, the Berne University Research Foundation, and the Swiss National 
Science Foundation (Grant nos. 200020-144420 and 206021139078) for financial support.

\section{References}

[1] B. Rosenberg, L. van Camp, E. B. Grimley, and A. J. Thomson, "The inhibition of growth or cell division in Escherichia coli by different ionic species of platinum(IV) complexes," The Journal of Biological Chemistry, vol. 242, no. 6, pp. 1347-1352, 1967.

[2] L. Kelland, "The resurgence of platinum-based cancer chemotherapy," Nature Reviews Cancer, vol. 7, no. 8, pp. 573-584, 2007.

[3] E. R. Jamieson and S. J. Lippard, "Structure, recognition, and processing of cisplatin-DNA adducts," Chemical Reviews, vol. 99, no. 9, pp. 2467-2498, 1999.

[4] N. J. Wheate, S. Walker, G. E. Craig, and R. Oun, "The status of platinum anticancer drugs in the clinic and in clinical trials," Dalton Transactions, vol. 39, no. 35, pp. 8113-8127, 2010.

[5] J. D. Roberts, J. Peroutka, G. Beggiolin, C. Manzotti, L. Piazzoni, and N. Farrell, "Comparison of cytotoxicity and cellular accumulation of polynuclear platinum complexes in L1210 murine leukemia cell lines," Journal of Inorganic Biochemistry, vol. 77, no. 1-2, pp. 47-50, 1999.

[6] J. Reedijk, "Improved understanding in platinium antitumour chemistry," Chemical Communications, no. 7, pp. 801-806, 1996.

[7] S. M. Cohen and S. J. Lippard, "Cisplatin: from DNA damage to cancer chemotherapy," Progress in Nucleic Acid Research and Molecular Biology, vol. 67, pp. 93-130, 2001.

[8] Z. H. Siddik, "Cisplatin: mode of cytotoxic action and molecular basis of resistance," Oncogene, vol. 22, no. 47, pp. 7265-7279, 2003.

[9] L. R. Kelland, G. Abel, M. J. McKeage et al., "Preclinical antitumor evaluation of bis-acetato-ammine-dichloro- cyclohexylamine platinum(IV): an orally active platinum drug," Cancer Research, vol. 53, no. 11, pp. 2581-2586, 1993.

[10] J. Holford, F. Raynaud, B. Murrer et al., "Chemical, biochemical and pharmacological activity of the novel sterically hindered platinum co-ordination complex, cis-[amminedichloro(2methylpyridine)] platinum(II) (AMD473)," Anti-Cancer Drug Design, vol. 13, no. 1, pp. 1-18, 1998.

[11] S. B. Howell, "The design and development of the tumortargeting nanopolymer dach platinum conjugate AP5346 (Prolindac ${ }^{\mathrm{TM}}$ )," in Platinum and Other Heavy Metal Compounds in Cancer Chemotherapy, A. Bonetti, R. Leone, F. Muggia, and S. B. Howell, Eds., Cancer Drug Discovery and Development, pp. 33-39, Humana Press, New York, NY, USA, 2009.

[12] M. Serova, A. Ghoul, K. Rezai et al., "In vitro anti-proliferative effects of Prolindac, a novel DACH-platinum linked polymer compound, as a single agent and in combination with other anti-cancer drugs," in Platinum and Other Heavy Metal Compounds in Cancer Chemotherapy: Molecular Mechanism and Clinical Applications, A. Bonetti, R. Leone, F. Muggia, and S. B. Howell, Eds., pp. 41-47, Humana Press, New York, NY, USA, 2009.

[13] T. Boulikas, "Low toxicity and anticancer activity of a novel liposomal cisplatin (Lipoplatin) in mouse xenografts," Oncology Reports, vol. 12, pp. 3-12, 2004.

[14] T. Boulikas, "Molecular mechanisms of cisplatin and its liposomally encapuslated form, LipoplatinTM as a chemotherapy and antiangiogenesis drug," Cancer Therapy, vol. 5, pp. 351-376, 2007.
[15] N. Farrell, Metal Ions in Biolgical Systems, Vol 42: Metal Complexes in Tumor Diagnosis and as Anticancer Agents, 2004.

[16] P. Perego, L. Gatti, C. Caserini et al., "The cellular basis of the efficacy of the trinuclear platinum complex BBR 3464 against cisplatin-resistant cells," Journal of Inorganic Biochemistry, vol. 77, no. 1-2, pp. 59-64, 1999.

[17] J. D. Roberts, J. Peroutka, and N. Farrell, "Cellular pharmacology of polynuclear platinum anti-cancer agents," Journal of Inorganic Biochemistry, vol. 77, no. 1-2, pp. 51-57, 1999.

[18] D. I. Jodrell, T. R. J. Evans, W. Steward et al., "Phase II studies of BBR3464, a novel tri-nuclear platinum complex, in patients with gastric or gastro-oesophageal adenocarcinoma," European Journal of Cancer, vol. 40, no. 12, pp. 1872-1877, 2004.

[19] N. Bertrand and J. C. Leroux, "The journey of a drug-carrier in the body: an anatomo-physiological perspective," Journal of Controlled Release, vol. 161, no. 2, pp. 152-163, 2012.

[20] K. Kataoka, A. Harada, and Y. Nagasaki, "Block copolymer micelles for drug delivery: design, characterization and biological significance," Advanced Drug Delivery Reviews, vol. 47, no. 1, pp. 113-131, 2001.

[21] H. Maeda, "The enhanced permeability and retention (EPR) effect in tumor vasculature: the key role of tumor-selective macromolecular drug targeting," Advances in Enzyme Regulation, vol. 41, pp. 189-207, 2001.

[22] H. Uchino, Y. Matsumura, T. Negishi et al., "Cisplatinincorporating polymeric micelles (NC-6004) can reduce nephrotoxicity and neurotoxicity of cisplatin in rats," British Journal of Cancer, vol. 93, no. 6, pp. 678-687, 2005.

[23] K. J. Haxton and H. M. Burt, "Polymeric drug delivery of platinum-based anticancer agents," Journal of Pharmaceutical Sciences, vol. 98, no. 7, pp. 2299-2316, 2009.

[24] R. Haag and F. Kratz, "Polymer therapeutics: concepts and applications," Angewandte Chemie\& International Edition, vol. 45, no. 8, pp. 1198-1215, 2006.

[25] D. E. Discher and A. Eisenberg, "Polymer vesicles," Science, vol. 297, no. 5583, pp. 967-973, 2002.

[26] P. Govender, B. Therrien, and G. S. Smith, "Bio-metallodendrimers-emerging strategies in metal-based drug design," European Journal of Inorganic Chemistry, no. 17, pp. 2853-2862, 2012.

[27] F. Arnesano and G. Natile, "Mechanistic insight into the cellular uptake and processing of cisplatin 30 years after its approval by FDA," Coordination Chemistry Reviews, vol. 253, no. 15-16, pp. 2070-2081, 2009.

[28] S. Bhattacharyya, R. A. Kudgus, R. Bhattacharya, and P. Mukherjee, "Inorganic nanoparticles in cancer therapy," Pharmaceutical Research, vol. 28, no. 2, pp. 237-259, 2011.

[29] D. K. Chan, D. M. Lieberman, S. Musatov, J. A. Goldfein, S. H. Selesnick, and M. G. Kaplitt, "Protection against cisplatininduced ototoxicity by adeno-associated virus-mediated delivery of the X-linked inhibitor of apoptosis protein is not dependent on caspase inhibition," Otology \& Neurotology, vol. 28, no. 3, pp. 417-425, 2007.

[30] K. Ajima, M. Yudasaka, T. Murakami, A. Maigné, K. Shiba, and S. Iijima, "Carbon nanohorns as anticancer drug carriers," Molecular Pharmaceutics, vol. 2, no. 6, pp. 475-480, 2005.

[31] R. P. Feazell, N. Nakayama-Ratchford, H. Dai, and S. J. Lippard, "Soluble single-walled carbon nanotubes as longboat delivery systems for platinum(IV) anticancer drug design," Journal of the American Chemical Society, vol. 129, no. 27, pp. 8438-8439, 2007. 
[32] B. Therrien, "Arene ruthenium cages: boxes full of surprises," European Journal of Inorganic Chemistry, vol. 2009, no. 17, pp. 2445-2453, 2009.

[33] M. Fujita, J. Yazaki, and K. Ogura, "Preparation of a macrocyclic polynuclear complex, [(en)Pd( $4,4^{\prime}$-bpy) $] 4(\mathrm{NO} 3) 8$ (en $=$ ethylenediamine, bpy $=$ bipyridine), which recognizes an organic molecule in aqueous media," Journal of the American Chemical Society, vol. 112, pp. 5645-5646, 1990.

[34] M. Fujita, D. Oguro, M. Miyazawa, H. Oka, K. Yamaguchi, and K. Ogura, "Self assembly of ten molecules into nanometre-sized organic host frameworks," Nature, vol. 378, no. 6556, pp. 469471, 1995.

[35] Y. M. Jeon, J. Kim, D. Whang, and K. Kim, "Molecular container assembly capable of conrolling binding and release of its guest molecules: Reversible encapsulation of organic molecules in sodium ion complexed cucurbituril," Journal of the American Chemical Society, vol. 118, no. 40, pp. 9790-9791, 1996.

[36] F. A. Cotton, C. Lin, and C. A. Murillo, "Supramolecular arrays based on dimetal building units," Accounts of Chemical Research, vol. 34, no. 10, pp. 759-771, 2001.

[37] M. Fujita, M. Tominaga, A. Hori, and B. Therrien, "Coordination assemblies from a $\mathrm{Pd}(\mathrm{II})$-cornered square complex," Accounts of Chemical Research, vol. 38, no. 4, pp. 369-378, 2005.

[38] C. Y. Su, Y. P. Cai, C. L. Chen, M. D. Smith, W. Kaim, and H. C. zur Loye, "Ligand-directed molecular architectures: Selfassembly of two-dimensional rectangular metallacycles and three-dimensional trigonal or tetragonal prisms," Journal of the American Chemical Society, vol. 125, no. 28, pp. 8595-8613, 2003.

[39] R. Chakrabarty, P. S. Mukherjee, and P. J. Stang, "Supramolecular coordination: self-assembly of finite two- and threedimensional ensembles," Chemical Reviews, vol. 111, no. 11, pp. 6810-6918, 2011.

[40] J. E. M. Lewis, E. L. Gavey, S. A. Cameron, and J. D. Crowley, "Stimuli-responsive $\mathrm{Pd}_{2} \mathrm{~L}_{4}$ metallosupramolecular cages: towards targeted cisplatin drug delivery," Chemical Science, vol. 3, no. 3, pp. 778-784, 2012.

[41] F. P. Dwyer, E. C. Gyarfas, W. P. Rogers, and J. H. Koch, "Biological activity of complex ions," Nature, vol. 170, no. 4318, pp. 190-191, 1952.

[42] M. J. Clarke, "Oncological implications of the chemistry of ruthenium," Metals Ions in Biological System, vol. 11, pp. 231-283, 1980.

[43] E. S. Antonarakis and A. Emadi, "Ruthenium-based chemotherapeutics: are they ready for prime time?" Cancer Chemotherapy and Pharmacology, vol. 66, no. 1, pp. 1-9, 2010.

[44] A. Bergamo and G. Sava, "Ruthenium anticancer compounds: myths and realities of the emerging metal-based drugs," Dalton Transactions, vol. 40, no. 31, pp. 7817-7823, 2011.

[45] W. H. Ang, A. Casini, G. Sava, and P. J. Dyson, "Organometallic ruthenium-based antitumor compounds with novel modes of action," Journal of Organometallic Chemistry, vol. 696, no. 5, pp. 989-998, 2011.

[46] J. M. Rademaker-Lakhai, D. van den Bongard, D. Pluim, J. H. Beijnen, and J. H. M. Schellens, "A phase I and pharmacological study with imidazolium-trans-DMSO-imidazoletetrachlororuthenate, a novel ruthenium anticancer agent," Clinical Cancer Research, vol. 10, no. 11, pp. 3717-3727, 2004.

[47] C. G. Hartinger, M. A. Jakupec, S. Zorbas-Seifried et al., "KP1019, a new redox-active anticancer agent-preclinical development and results of a clinical phase I study in tumor patients," Chemistry and Biodiversity, vol. 5, no. 10, pp. 2140$2155,2008$.
[48] P. Heffeter, B. Atil, K. Kryeziu et al., "The ruthenium compound KP1339 potentiates the anticancer activity of sorafenib in vitro and in vivo," European Journal of Cancer, vol. 49, no. 15, pp. 3366-3375, 2013.

[49] G. Süss-Fink, "Arene ruthenium complexes as anticancer agents," Dalton Transactions, vol. 39, no. 7, pp. 1673-1688, 2010.

[50] C. S. Allardyce, P. J. Dyson, D. J. Ellis, and S. L. Heath, "[Ru(eta)6-p-cymene)Cl-2(pta)] (pta=1,3,5-triaza-7-phosphatricyclo[3.3.1.1] decane): a water soluble compound that exhibits $\mathrm{pH}$ dependent DNA binding providing selectivity for diseased cells," Chemical Communications, pp. 1396-1397, 2001.

[51] C. Scolaro, A. Bergamo, L. Brescacin et al., "In vitro and in vivo evaluation of ruthenium(II)-arene PTA complexes," Journal of Medicinal Chemistry, vol. 48, no. 12, pp. 4161-4171, 2005.

[52] W. H. Ang, E. Daldini, C. Scolaro, R. Scopelliti, L. JuilleratJeannerat, and P. J. Dyson, "Development of organometallic ruthenium-arene anticancer drugs that resist hydrolysis," Inorganic Chemistry, vol. 45, no. 22, pp. 9006-9013, 2006.

[53] R. E. Aird, J. Cummings, A. A. Ritchie et al., "In vitro and in vivo activity and cross resistance profiles of novel ruthenium (II) organometallic arene complexes in human ovarian cancer," British Journal of Cancer, vol. 86, no. 10, pp. 1652-1657, 2002.

[54] R. A. Zelonka and M. C. Baird, "Reactions of benzene complexes of ruthernium(II)," Journal of Organometallic Chemistry, vol. 35, no. 1, pp. C43-C46, 1972.

[55] G. Süss-Fink, "Water-soluble arene ruthenium complexes: from serendipity to catalysis and drug design," Journal of Organometallic Chemistry, vol. 751, pp. 2-19, 2014.

[56] G. Süss-Fink and B. Therrien, "Dinuclear ruthenium and osmium arene trihydrido complexes: versatile water-soluble synthons in organometallic chemistry," Organometallics, vol. 26, no. 4, pp. 766-774, 2007.

[57] F. A. Egbewande, L. E. H. Paul, B. Therrien, and J. Furrer, "Synthesis, characterization and cytotoxicity of $\left(\eta^{6}-\mathrm{p}\right.$ cymene)ruthenium(II) complexes of $\alpha$-amino acids," European Journal of Inorganic Chemistry, vol. 2014, no. 7, pp. 1174-1184, 2014.

[58] H. Yan, G. Süss-Fink, A. Neels, and H. Stoeckli-Evans, "Mono-, di- and tetra-nuclear p-cymeneruthenium complexes containing oxalato ligands," Journal of the Chemical Society, Dalton Transactions, vol. 1997, no. 22, pp. 4345-4350, 1997.

[59] F. Linares, M. A. Galindo, S. Galli, M. A. Romero, J. A. R. Navarro, and E. Barea, "Tetranuclear coordination assemblies based on half-sandwich ruthenium(II) complexes: noncovalent binding to DNA and cytotoxicity," Inorganic Chemistry, vol. 48, no. 15, pp. 7413-7420, 2009.

[60] J. Mattsson, P. Govindaswamy, A. K. Renfrew et al., "Synthesis, molecular structure and anticancer activity of cationic arene ruthenium metallarectangles," Organometallics, vol. 28, no. 15, pp. 4350-4357, 2009.

[61] B. H. Northrop, Y.-R. Zheng, K.-W. Chi, and P. J. Stang, "Selforganization in coordination-driven self-assembly," Accounts of Chemical Research, vol. 42, no. 10, pp. 1554-1563, 2009.

[62] V. Vajpayee, Y. H. Song, M. H. Lee et al., "Self-assembled areneruthenium-based rectangles for the selective sensing of multicarboxylate anions," Chemistry, vol. 17, no. 28, pp. 7837-7844, 2011.

[63] V. Vajpayee, Y. H. Song, Y. J. Jung et al., "Coordination-driven self-assembly of ruthenium-based molecular-rectangles: synthesis, characterization, photo-physical and anticancer potency studies," Dalton Transactions, vol. 41, no. 10, pp. 3046-3052, 2012. 
[64] V. Vajpayee, S. Lee, S. Kim et al., "Self-assembled metallarectangles bearing azodipyridyl ligands: synthesis, characterization and antitumor activity," Dalton Transactions, vol. 42, no. 2, pp. 466-475, 2013.

[65] V. Vajpayee, S. M. Lee, J. W. Park et al., "Growth inhibitory activity of a bis-benzimidazole-bridged arene ruthenium metallarectangle and -prism," Organometallics, vol. 32, no. 6, pp. 15631566, 2013.

[66] N. P. E. Barry, F. Edafe, and B. Therrien, "Anticancer activity of tetracationic arene ruthenium metalla-cycles," Dalton Transactions, vol. 40, no. 27, pp. 7172-7180, 2011.

[67] G. Gupta, B. Murray, P. Dyson, and B. Therrien, "Synthesis, molecular structure and cytotoxicity of molecular materials based on water soluble half-sandwich $\mathrm{Rh}(\mathrm{III})$ and $\operatorname{Ir}(\mathrm{III})$ tetranuclear metalla-cycles," Materials, vol. 6, no. 11, pp. 53525366, 2013.

[68] N. P. E. Barry, F. Edafe, P. J. Dyson, and B. Therrien, "Anticancer activity of osmium metalla-rectangles," Dalton Transactions, vol. 39, no. 11, pp. 2816-2820, 2010.

[69] P. Govindaswamy, D. Linder, J. Lacour, G. Süss-Fink, and B. Therrien, "Self-assembled hexanuclear arene ruthenium metallo-prisms with unexpected double helical chirality," Chemical Communications, no. 45, pp. 4691-4693, 2006.

[70] N. P. E. Barry, M. Austeri, J. Lacour, and B. Therrien, "Highly efficient NMR enantiodiscrimination of chiral octanuclear metalla-boxes in polar solvent," Organometallics, vol. 28, no. 16, pp. 4894-4897, 2009.

[71] N. P. E. Barry, N. H. Abd Karim, R. Vilar, and B. Therrien, "Interactions of ruthenium coordination cubes with DNA," Dalton Transactions, no. 48, pp. 10717-10719, 2009.

[72] N. P. E. Barry, J. Furrer, J. Freudenreich, G. Süss-Fink, and B. Therrien, "Designing the host-guest properties of tetranuclear arene ruthenium metalla-rectangles to accommodate a pyrene molecule," European Journal of Inorganic Chemistry, vol. 2010, no. 5, pp. 725-728, 2010.

[73] C. S. Johnson, "Diffusion ordered nuclear magnetic resonance spectroscopy: principles and applications," Progress in Nuclear Magnetic Resonance Spectroscopy, vol. 34, no. 3-4, pp. 203-256, 1999.

[74] Y. Cohen, L. Avram, and L. Frish, "Diffusion NMR spectroscopy in supramolecular and combinatorial chemistry: an old parameter-new insights," Angewandte Chemie, vol. 44, no. 4, pp. 520-554, 2005.

[75] N. P. E. Barry, J. Furrer, and B. Therrien, "In- and outof-cavity interactions by modulating the size of ruthenium metallarectangles," Helvetica Chimica Acta, vol. 93, no. 7, pp. 1313-1328, 2010.

[76] P. Govindaswamy, J. Furrer, G. Süss-Fink, and B. Therrien, "Encapsulation of triphenylene derivatives in the hexanuclear arene ruthenium metallo-prismatic cage $\left[\mathrm{Ru}_{6}(p\right.$ $\left.\left.\operatorname{Pr}^{i} \mathrm{C}_{6} \mathrm{H}_{4} \mathrm{Me}\right)_{6}(\mathrm{tpt})_{2}(\mathrm{dhbq})_{3}\right]^{6+} \quad(\mathrm{tpt}=2,4,6$-tri(pyridin-4-yl $)$ 1,3,5-triazine, dhbq=2,5-dihydroxy-1,4-benzoquinonato)," Zeitschrift für Anorganische und Allgemeine Chemie, vol. 634, no. 8, pp. 1349-1352, 2008.

[77] J. Mattsson, P. Govindaswamy, J. Furrer et al., "Encapsulation of aromatic molecules in hexanuclear arene ruthenium cages: a strategy to build up organometallic carceplex prisms with a dangling arm standing out," Organometallics, vol. 27, no. 17, pp. 4346-4356, 2008.

[78] N. P. E. Barry and B. Therrien, "Host-guest chemistry in the hexanuclear (arene)ruthenium metalla-prismatic cage
$\left[\mathrm{Ru}_{6}(p \text {-cymene })_{6}(\mathrm{tpt})_{2}(\mathrm{dhnq})_{3}\right]^{6+,}$, European Journal of Inorganic Chemistry, vol. 2009, no. 31, pp. 4695-4700, 2009.

[79] J. Freudenreich, N. P. E. Barry, G. Süss-Fink, and B. Therrien, "Permanent encapsulation or host-guest behavior of aromatic molecules in hexanuclear arene ruthenium prisms," European Journal of Inorganic Chemistry, vol. 2010, no. 16, pp. 2400-2405, 2010.

[80] B. Therrien, G. Süss-Fink, P. Govindaswamy, A. K. Renfrew, and P. J. Dyson, "The "complex-in-a-complex" cations $\left[(\mathrm{acac}) 2 \mathrm{McRu}_{6}\left(p-\mathrm{iPrC}_{6} \mathrm{H}_{4} \mathrm{Me}\right)_{6}(\mathrm{tpt})_{2}(\mathrm{dhbq})_{3}\right]^{6+}:$ a trojan horse for cancer cells," Angewandte Chemie-International Edition, vol. 47, no. 20, pp. 3773-3776, 2008.

[81] J. Mattsson, O. Zava, A. K. Renfrew et al., "Drug delivery of lipophilic pyrenyl derivatives by encapsulation in a water soluble metalla-cage," Dalton Transactions, vol. 39, no. 35, pp. 8248-8255, 2010.

[82] N. P. E. Barry, O. Zava, P. J. Dyson, and B. Therrien, “Excellent correlation between drug release and portal size in metallacage drug-delivery systems," Chemistry, vol. 17, no. 35, pp. 96699677, 2011.

[83] K. D. Tew, "Glutathione-associated enzymes in anticancer drug resistance," Cancer Research, vol. 54, no. 16, pp. 4313-4320, 1994.

[84] D. M. Townsend and K. D. Tew, "The role of glutathione-Stransferase in anti-cancer drug resistance," Oncogene, vol. 22, no. 47, pp. 7369-7375, 2003.

[85] A. Pitto-Barry, N. P. E. Barry, O. Zava, R. Deschenaux, and B. Therrien, "Encapsulation of pyrene-functionalized poly(benzyl ether) dendrons into a water-soluble organometallic cage," Chemistry: An Asian Journal, vol. 6, no. 6, pp. 1595-1603, 2011.

[86] A. Pitto-Barry, N. P. E. Barry, O. Zava, R. Deschenaux, P. J. Dyson, and B. Therrien, "Double targeting of tumours with pyrenyl-modified dendrimers encapsulated in an areneruthenium metallaprism," Chemistry - A European Journal, vol. 17, no. 6, pp. 1966-1971, 2011.

[87] A. Pitto-Barry, O. Zava, P. J. Dyson, R. Deschenaux, and B. Therrien, "Enhancement of cytotoxicity by combining pyrenyldendrimers and arene ruthenium metallacages," Inorganic Chemistry, vol. 51, no. 13, pp. 7119-7124, 2012.

[88] B. W. Henderson and T. J. Dougherty, "How does photodynamic therapy work?" Photochemistry and Photobiology, vol. 55, no. 1, pp. 145-157, 1992.

[89] T. J. Dougherty, C. J. Gomer, B. W. Henderson et al., "Photodynamic therapy," Journal of the National Cancer Institute, vol. 90, no. 12, pp. 889-905, 1998.

[90] M. Ferrari, "Cancer nanotechnology: opportunities and challenges," Nature Reviews Cancer, vol. 5, no. 3, pp. 161-171, 2005.

[91] J. Freudenreich, C. Dalvit, G. Süss-Fink, and B. Therrien, "Encapsulation of photosensitizers in hexa- and octanuclear organometallic cages: synthesis and characterization of carceplex and host-guest systems in solution," Organometallics, vol. 32, no. 10, pp. 3018-3033, 2013.

[92] B. Therrien, "Transporting and shielding photosensitisers by using water-soluble organometallic cages: a new strategy in drug delivery and photodynamic therapy," Chemistry, vol. 19, no. 26, pp. 8378-8386, 2013.

[93] F. Schmitt, J. Freudenreich, N. P. E. Barry, L. Juillerat-Jeanneret, G. Süss-Fink, and B. Therrien, "Organometallic cages as vehicles for intracellular release of photosensitizers," Journal of the American Chemical Society, vol. 134, no. 2, pp. 754-757, 2012.

[94] L. E. H. Paul, B. Therrien, and J. Furrer, "Investigation of the reactivity between a ruthenium hexacationic prism and 
biological ligands," Inorganic Chemistry, vol. 51, no. 2, pp. 10571067, 2012.

[95] L. E. H. Paul, B. Therrien, J. Furrer, and J. Biol, "Interaction of a ruthenium hexacationic prism with amino acids and biological ligands: ESI mass spectrometry and NMR characterisation of the reaction products," Journal of Biological Inorganic Chemistry, vol. 17, no. 7, pp. 1053-1062, 2012.

[96] M. Hanif, H. Henke, S. M. Meier et al., "Is the reactivity of M(II)-arene complexes of 3-hydroxy-2(1 H)-pyridones to biomolecules the anticancer activity determining parameter," Inorganic Chemistry, vol. 49, no. 17, pp. 7953-7963, 2010.

[97] L. E. H. Paul, J. Furrer, and B. Therrien, "Reactions of a cytotoxic hexanuclear arene ruthenium assembly with biological ligands," Journal of Organometallic Chemistry, vol. 734, pp. 45-52, 2013. 

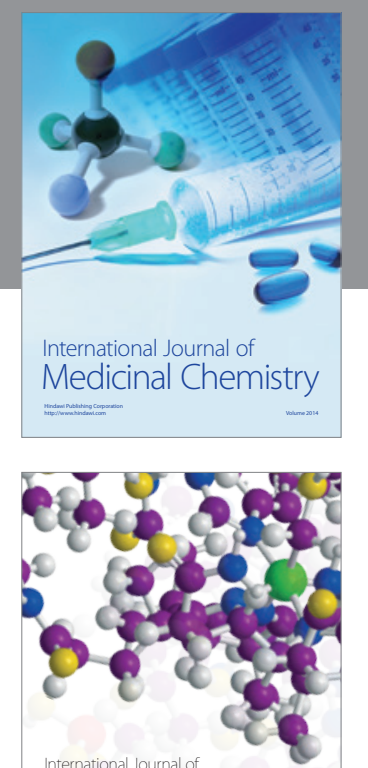

\section{Carbohydrate} Chemistry

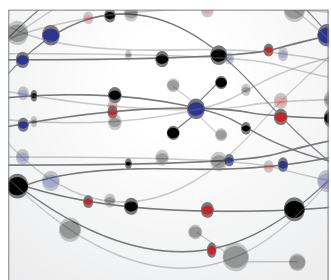

The Scientific World Journal
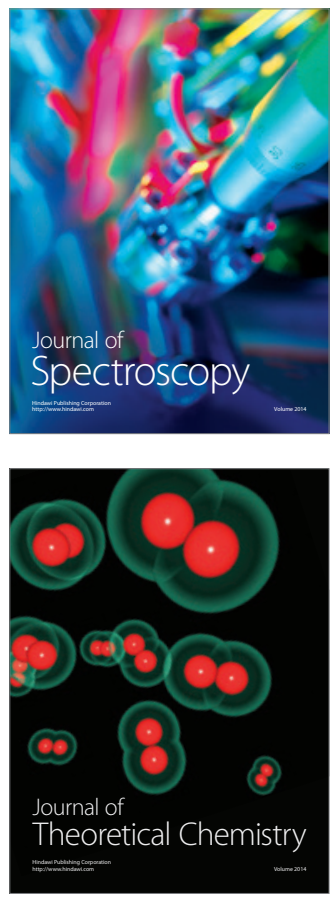
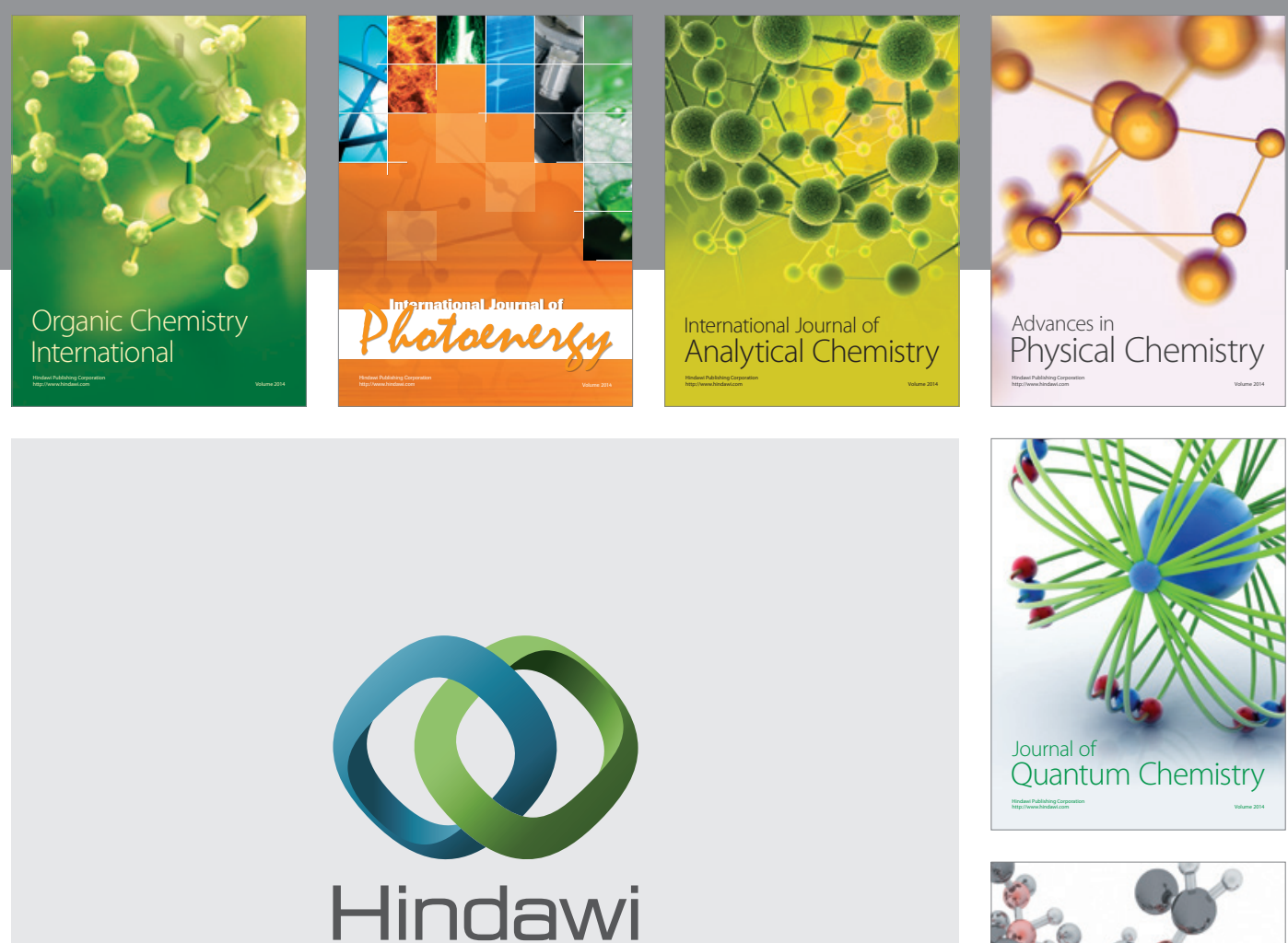

Submit your manuscripts at

http://www.hindawi.com

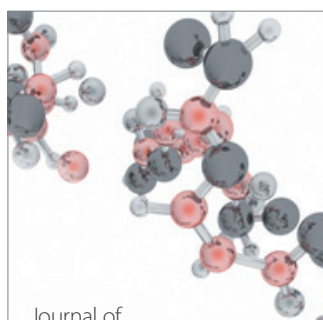

Analytical Methods

in Chemistry

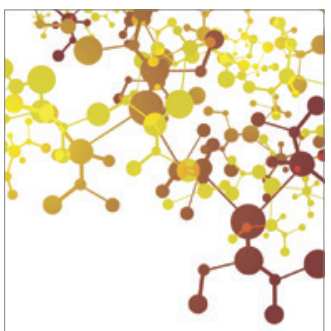

Journal of

Applied Chemistry

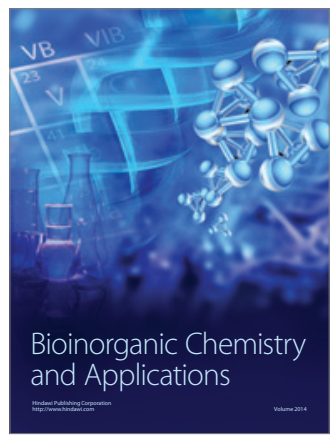

Inorganic Chemistry
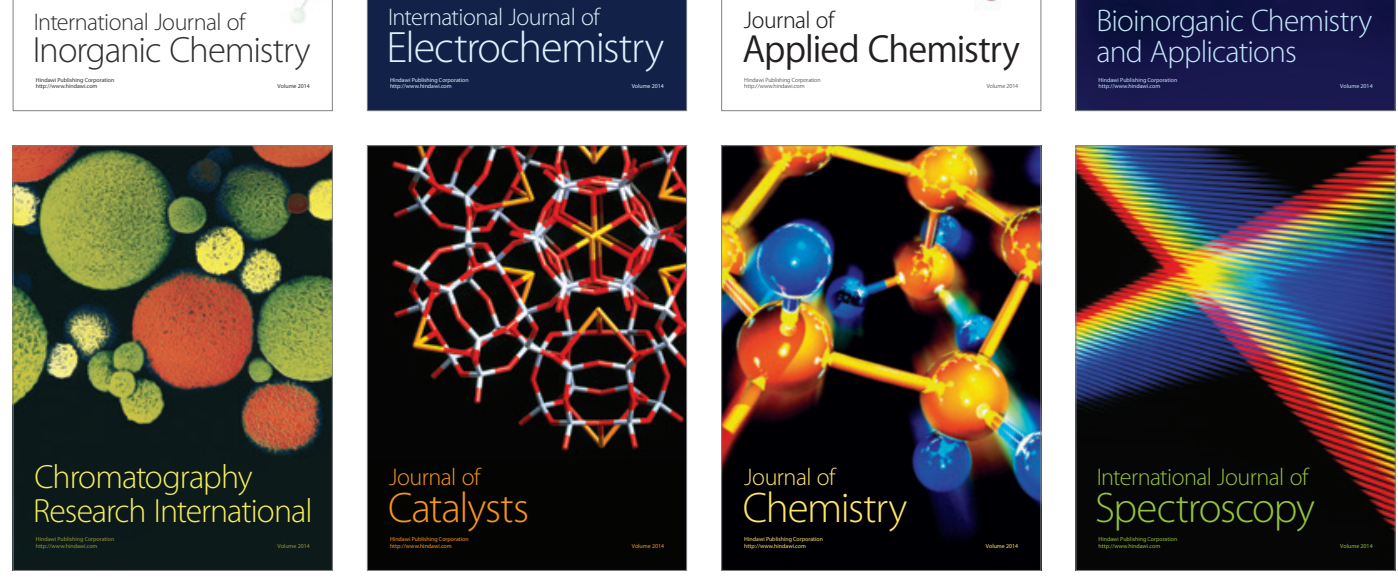